\title{
Article \\ Maximization of Water Productivity and Yield of Two Iceberg Lettuce Cultivars in Hydroponic Farming System Using Magnetically Treated Saline Water
}

\author{
Abdelaziz M. Okasha 1(D), Eman M. Eldib 1(D), Adel H. Elmetwalli ${ }^{2}$, Aitazaz Ahsan Farooque ${ }^{3,4}$, \\ Zaher Mundher Yaseen ${ }^{5,6,7, *}$ and Salah Elsayed ${ }^{8}$ iD
}

check for updates

Citation: Okasha, A.M.; Eldib, E.M.; Elmetwalli, A.H.; Farooque, A.A.; Yaseen, Z.M.; Elsayed, S.

Maximization of Water Productivity and Yield of Two Iceberg Lettuce Cultivars in Hydroponic Farming System Using Magnetically Treated Saline Water. Agriculture 2022, 12, 101. https://doi.org/10.3390/ agriculture12010101

Academic Editors: Vítor João Pereira Domingues Martinho, Paulo

Reis Mourão and

Nikolaos Georgantzis

Received: 17 December 2021

Accepted: 9 January 2022

Published: 12 January 2022

Publisher's Note: MDPI stays neutral with regard to jurisdictional claims in published maps and institutional affiliations.

Copyright: (C) 2022 by the authors. Licensee MDPI, Basel, Switzerland. This article is an open access article distributed under the terms and conditions of the Creative Commons Attribution (CC BY) license (https:// creativecommons.org/licenses/by/ $4.0 /)$.
1 Department of Agricultural Engineering, Faculty of Agriculture, Kafrelsheikh University, Kafr El-Sheikh 33516, Egypt; abdelaziz.okasha@agr.kfs.edu.eg (A.M.O.); eman_bedeer@agr.kfs.edu.eg (E.M.E.)

2 Department of Agricultural Engineering, Faculty of Agriculture, Tanta University, Tanta 31527, Egypt; adel.elmetwali@agr.tanta.edu.eg

3 Faculty of Sustainable Design Engineering, University of Prince Edward Island, Charlottetown, PE C1A4P3, Canada; afarooque@upei.ca

4 School of Climate Change and Adaptation, University of Prince Edward Island, Charlottetown, PE C1A4P3, Canada

5 Department of Urban Planning, Engineering Networks and Systems, Institute of Architecture and Construction, South Ural State University, 76, Lenin Prospect, 454080 Chelyabinsk, Russia

6 New Era and Development in Civil Engineering Research Group, Scientific Research Center, Al-Ayen University, Nasiriyah 64001, Iraq

7 College of Creative Design, Asia University, Taichung 41354, Taiwan

8 Agricultural Engineering, Evaluation of Natural Resources Department, Environmental Studies and Research Institute, University of Sadat City, Sadat City 32897, Egypt; salah.emam@esri.usc.edu.eg

* Correspondence: yaseen@alayen.edu.iq

Abstract: Egypt has limited agricultural land, associated with the scarcity of irrigation water and rapid population growth. Hydroponic farming, seawater desalination and magnetic treatment are among the practical solutions for sustaining rapid population growth. In this regard, the main objective of the present research study was to design and construct a hierarchical engineering unit as a hydroponic farming system (soilless) to produce an iceberg lettuce crop using magnetically treated saline water. The treatments included four types of irrigation water: common irrigation water $\left(\mathrm{IW}_{1}\right)$ with an electrical conductivity (EC) of $0.96 \mathrm{dS} / \mathrm{m}$ as a control treatment, magnetically treated common irrigation water $\left(\mathrm{IW}_{2}\right)$ with an EC of $0.96 \mathrm{dS} / \mathrm{m}$, saline water $\left(\mathrm{IW}_{3}\right)$ with an EC of $4.56 \mathrm{dS} / \mathrm{m}$ and magnetically treated saline water $\left(\mathrm{IW}_{4}\right)$ with an EC of $4.56 \mathrm{dS} / \mathrm{m}$; three depletion ratios (DR) of field capacity $\left(\mathrm{DR}_{0}=50 \%, \mathrm{DR}_{1}=60 \%\right.$ and $\left.\mathrm{DR}_{2}=70 \%\right)$ and three slopes of hydroponic pipes $\left(S_{1}=0.0 \%, S_{2}=0.025 \%\right.$ and $\left.S_{3}=0.075 \%\right)$. The results revealed that seawater contributed $7.15 \%$ to produce iceberg lettuce in the hydroponic system. The geometric parameter, the slope of the pipes, influenced the obtained luminous intensity by an average increase of $21 \%$ and $71 \%$ for $S_{2}$ and $S_{3}$, respectively, compared with the zero slope (horizontal pipes). Magnetization of irrigation water increased the total soluble solids (TSS) and enhanced the fresh weight and water productivity of both iceberg lettuce varieties used. The maximum percentages of TSS were $5.20 \%$ and $5.10 \%$ for lemur and iceberg 077, respectively, for the combination $\mathrm{IW}_{4} \mathrm{DR}_{2} \mathrm{~S}_{2}$. The highest values of fresh weight and water productivity of $3.10 \mathrm{~kg} / \mathrm{m}$ and $39.15 \mathrm{~kg} / \mathrm{m}^{3}$ were recorded with the combinations $\mathrm{IW}_{3} \mathrm{DR}_{2} \mathrm{~S}_{3}$ and $\mathrm{IW}_{4} \mathrm{DR}_{1} \mathrm{~S}_{3}$, respectively, for lemur and iceberg lettuce. The percentages of these increases were $109.46 \%$ and $97.78 \%$, respectively, when compared with the combination $\mathrm{IW}_{1} \mathrm{DR}_{0} \mathrm{~S}_{1}$. The highest values of iceberg lettuce 077 fresh weight and water productivity were $2.93 \mathrm{~kg} / \mathrm{m}$ and $36.15 \mathrm{~kg} / \mathrm{m}^{3}$, respectively, which were recorded with the combination $\mathrm{IW}_{4} \mathrm{DR}_{1} \mathrm{~S}_{3}$. The percentages of these increases were $112.32 \%$ and $120.56 \%$, respectively, when compared with $\mathrm{IW}_{1} \mathrm{DR}_{0} \mathrm{~S}_{1}$ (the control treatment). 
Keywords: magnetic water treatment; hydroponics; soilless; iceberg lettuce; seawater; water productivity

\section{Introduction}

In Egypt, the reclamation of newly cultivated areas is a challenge from the economic point of view, and existing cultivated regions are affected by seawater encroachment, such as the Kafr El-Sheikh region which overlooks the Mediterranean Sea coast [1,2]. Like many other countries in arid and semi-arid regions, Egypt also suffers from limited natural resources, including fertile cultivated areas and fresh irrigation water associated with rapid population growth [3-6]. In this context, to sustainably feed the increased population, new promising methods for producing adequate food are compulsory. Modern farming systems (e.g., hydroponic farming) must be used to produce needed vegetables and fruits [7-9]. The hydroponic farming systems have developed a new farming idea which only needs a small area and produces good results in less space and time than conventional farming systems. As an alternative, it can be a sustainable source of food [10]. Additionally, hydroponic farming may be successfully used for growing healthy food crops or vegetables [11]. Moreover, available commercial hydroponic farming systems are normally automatically operated, which decreases labor and other conventional cultivation practices (e.g., tilling, weeding and spraying) [12]. Moreover, hydroponic farming systems save remarkable amounts of water, and the problems of pests and diseases can be controlled [13]. This farming system is obviously one of the most promising techniques for the future [14]. The lettuce production system grown in conventional soil was the least efficient in the use of water when compared to hydroponics, which increases the efficiency of water use and reduces the days required for each harvest cycle of the crop. Moreover, it also helps to raise the quality values, including chlorophyll and total soluble solids, as well as increase the yield and profitability of production, which increases food production $[15,16]$.

Water scarcity is a main limiting factor and big challenge for many countries worldwide, especially in arid and semi-arid environments [17-19]. To overcome the problem of water salinity and shortage, magnetic treatments would be a reliable technique. Recently, researchers in the field of agricultural crop production have been trying to use low-water-quality resources as a result of a lack of fresh water [20-23]. One of the suggested techniques is the magnetization of saline water, which aims to change the water properties to make it more suitable for irrigation. Magnetic treatment of saline water is a non-chemical and environmentally friendly technology that increases agricultural yields without using any chemicals [24,25]. Magnetization mainly changes the atomic, molecular and electronic structure of the treated water, such as changes to its solidifying and boiling point, viscosity and dielectric constant, the formation of clustering structures from linear and ring hydrogen-bound chains of molecules, the magnetic interaction between these clustering structures and the increasing polarization effects of the water molecules [26-32].

Several studies have assessed the potential of magnetically treated saline and nonsaline water to enhance the yield and water productivity of various crops, including pea, strawberry, tomato, eggplant, faba bean, maize and sunflower [26-32]. Water productivity can be increased for leafy and vegetable crops using magnetically treated water [33]. Under greenhouse conditions, magnetic water treatments were employed to improve chickpea growth parameters, chemical contents and productivity [34]. The magnetization of the water led to an increase in the overall output of the common bean, including the photosynthesis, the translocation efficiency and the total chlorophyll [35]. El-Mesery et al. [29] concluded that saline water magnetization led to decreased surface tension, $\mathrm{pH}$, boiling point, total soluble solids (TSS) and the electrical conductivity (EC) of the water. The number of leaves and the fresh weight of the lettuce increased when irrigated by magnetically treated water relative to normal water [36]. Moreover, the magnetization effect was strongly influenced by the magnetic field strength (MFS), with an MFS of $300 \mathrm{mT}$ 
determined to be the best magnetizing condition [37]. The effect of the irrigation water types (tap water, magnetized water) and the ammonium sulphate levels $(0,7$ and $14 \mathrm{~g} / \mathrm{pot})$, as well as their interaction, on the vegetative growth and the oil production of the marjoram (Majorana hortensis L.) plant was investigated. They found that marjoram plants responded significantly to various types of irrigation, as well as nitrogen fertilization, and their interactions [38].

Magnetically treated irrigation water increased the water use efficiency and yield of watermelon when compared to the non-magnetic water-irrigated watermelon, since it improved the nutritional qualities of watermelon by increasing the content of moisture, carbohydrate, crude protein, ash, crude fiber, fat and oil [31]. Hozayn [39] compared magnetized and non-magnetized saline water for irrigating barley plants and demonstrated that the grain yield increased by $14.75 \%, 14.32 \%, 16.06 \%, 12.97 \%$ and $15.85 \%$ at salinity levels of 320, 2000, 4000, 6000 and 8000 ppm, respectively. They also revealed that irrigating barley plants with magnetized water reduced the harmful effects of salinity stress, and irrigation with magnetized saline water improved the barley growth parameters and increased the amount of photosynthetic pigments, which resulted in higher grain yields. Additionally, the magnetization process of water can increase plant productivity and increase the number of bolls of cotton plants, as well as increase the weight of the bolls for each plant [40].

As a potential solution to increase the production of various crops through the horizontal expansion of the cultivated area, saline water from different sources can be utilized after decreasing the harmful effects of salinity, either by mixing it with freshwater resources to reduce the salinity level or by treating the saline water by magnetization. The urgent need for new technologies that make the use of saline water safer for growing food crops without losing quality, along with increasing the final yield, supports the hypothesis that there is a positive impact in crop quality and yield when low-quality water is subjected to magnetization.

From the above-mentioned review, and because of insufficient water supplies in arid and semi-arid regions, magnetically treated saline water could be a possible solution based on the hypothesis that it will improve various chemical water properties. To the best of our knowledge, no previous studies have applied hydroponic farming systems using magnetically treated saline water to maximize the water productivity and yield of iceberg lettuce. Moreover, there are no previous studies that have tested the effects of moisture depletion rates and the slopes of hydroponic piping systems in lettuce properties.

In this sense, the main objectives of the present study were to: (i) Design and construct a hierarchical engineering unit as a hydroponic farming system (soilless) to produce an iceberg lettuce crop using magnetically treated saline irrigation water; (ii) Investigate the effect of the moisture depletion ratio as a percent of the field capacity on lettuce properties; (iii) Study the effect of the slope of the hydroponic system pipes on lettuce properties.

\section{Materials and Methods}

\subsection{Experiment Site and Structures}

The experiments were constructed and carried out at the Experimental Farm of Kafrelsheikh University $\left(31^{\circ} 05^{\prime} \mathrm{N}\right.$ latitude, $30^{\circ} 57^{\prime} \mathrm{E}$ longitude and $6 \mathrm{~m}$ altitude) in two successive seasons of 2018/2019 for lemur iceberg lettuce and 2019/2020 for 077 iceberg lettuce to evaluate the effects of the slope of the piping system and the depletion ratio under four different water qualities (common irrigation water $\left(\mathrm{IW}_{1}\right)$, magnetically treated common irrigation water $\left(\mathrm{IW}_{2}\right)$, saline water $\left(\mathrm{IW}_{3}\right)$ and magnetically treated saline water $\left(\mathrm{IW}_{4}\right)$ ). Two hierarchical engineering units as a hydroponic system (soilless) were designed and constructed as depicted in Appendix A. The first system consists of three main components: three iron stands of $1.5 \mathrm{~m}$ height in the form of a pyramid (vertical expansion) and eighteen $10 \mathrm{~cm}$ diameter PVC pipes that are $2 \mathrm{~m}$ long. Each pipe has eight holes of $7 \mathrm{~cm}$ in diameter for the plants to exit, spaced at $20 \mathrm{~cm}$. Pipes were filled with a soil mixture, PittMoss (Ambridge, PA, USA) and vermiculite, at a ratio of 1:3. The third component of the system was the irrigation system with a magnetic treatment unit, having two tanks (1 and 2) of $1000 \mathrm{~L}$ 
capacity each, a motor/pump with an output power of $0.37 \mathrm{~kW}$, a $5.3 \mathrm{~L} / \mathrm{min}$ flow rate and a 0.5 bar operating pressure, and a magnetic treatment device with an input and output orifice for magnetic water of $1.27 \mathrm{~cm}$ diameter. The intensity of the magnetic field was measured using an analog Hall effect sensor (analog magnetic effect sensor). The sensor and the measuring circuits were calibrated to a memo calibration device and a permanent magnet with a Gaussian strength of $667.5 \mathrm{mT}$ on the north pole and $405.5 \mathrm{mT}$ on the south pole was used to ensure adequate exposure to the magnetic field. A drip irrigation network was used for the experiment with a screen filter, pressure regulator, pressure gauges, a flowmeter and control valves. The main line was made from PVC pipes of $1.9 \mathrm{~cm}$ outer diameter. Lateral drip lines were made from PE pipes of $16 \mathrm{~mm}$ outer diameter equipped with GR emitters of $4 \ell / \mathrm{h}$ rated discharge and spaced at $20 \mathrm{~cm}$. A similar system was also used, having the same components but without the magnetic device.

\subsection{Iceberg Lettuce}

Iceberg lettuce (Lactuca Sativa, L) was planted in incubation trays and then transferred after 4 to 5 weeks to the planting pipes of the hydroponic system in both seasons. The first season started on 4 November 2018 until 10 January 2019 for the lemur iceberg lettuce. The second season lasted for 69 days and started from 24 December 2019 to 2 March 2020 for the iceberg lettuce 077 .

\subsection{Analysis of Water and Soil Mixture}

Samples of the soil mixture and water were collected for chemical analysis (e.g., the anions and cations). The analysis was done at the Central Laboratory of Environmental Studies, Faculty of Agriculture, Kafrelsheikh University, as presented in Table 1. The soil mixture was dried in open air conditions and then ground. Electrical conductivity and $\mathrm{pH}$ were determined in media/water $(1: 10 w / v)$ as described by Smith and Hughes [41]. Soluble cations and anions were determined as described by Jackson [42]. Physiochemical parameters, comprising EC, hydrogen ion activity $(\mathrm{pH})$, major cations $\left(\mathrm{Ca}^{2+}, \mathrm{Mg}^{2+}\right.$, $\left.\mathrm{Na}^{+}, \mathrm{K}^{+}\right)$and major anions $\left(\mathrm{Cl}^{-}, \mathrm{HCO}_{3}{ }^{-}, \mathrm{SO}_{4}{ }^{2-}\right)$, which are indicators of water, were determined according to standard analytical methods. $\mathrm{EC}$ and $\mathrm{pH}$ were recorded using a portable calibrated conductivity multi-parameter instrument (Hanna HI 9033), which was calibrated using standard solutions. The concentrations of $\mathrm{Ca}^{2+}$ and $\mathrm{Mg}^{2+}$ were determined using the EDTA titrimetric method (ethylenediamine tetra-acetic acid), while $\mathrm{K}^{+}$and $\mathrm{Na}^{+}$ concentrations were analyzed using a flame photometer (ELEX 6361, Eppendorf AG, Hamburg, Germany). The concentration of $\mathrm{Cl}^{-}$was estimated by titration using silver nitrate and the $\mathrm{HCO}_{3}{ }^{-}$concentration was determined using the titrimetric method. The content of $\mathrm{SO}_{4}{ }^{2-}$ was determined using an ultraviolet (UV) visible spectrophotometer (DR/2040, Loveland, CO, USA). Pre-prepared mixed water of irrigation water and seawater at a ratio of 13:1 was done and then was magnetically treated using a magnetization device. Field capacity and wilting point of the soil mixture was $286.63 \%$ and $157.49 \%$, respectively.

Table 1. Chemical analysis of water and soil mixture including EC, $\mathrm{pH}$, anions and cations.

\begin{tabular}{|c|c|c|c|c|c|c|c|c|c|c|}
\hline & \multirow[b]{2}{*}{ Water Type } & \multirow{2}{*}{$\begin{array}{c}\text { EC, } \\
\mathrm{dS} / \mathrm{m}\end{array}$} & \multirow[b]{2}{*}{$\mathrm{pH}$} & \multicolumn{4}{|c|}{ Cations } & \multicolumn{3}{|c|}{ Anions } \\
\hline & & & & $\begin{array}{c}\mathrm{Ca}^{2+} \\
\mathrm{meq} / \mathrm{L}\end{array}$ & $\begin{array}{c}\mathrm{Mg}^{2+} \\
\mathrm{meq} / \mathrm{L}\end{array}$ & $\begin{array}{c}\mathrm{Na}^{+} \\
\mathrm{meq} / \mathrm{L}\end{array}$ & $\begin{array}{c}\mathrm{K}^{+} \\
\mathrm{meq} / \mathrm{L}\end{array}$ & $\begin{array}{c}\mathrm{Cl}^{-} \\
\mathrm{meq} / \mathrm{L}\end{array}$ & $\begin{array}{c}\mathrm{HCO}_{3}^{-} \\
\mathrm{meq} / \mathrm{L}\end{array}$ & $\begin{array}{l}\mathrm{SO}_{4}{ }^{2-} \\
\mathrm{meq} / \mathrm{L}\end{array}$ \\
\hline \multirow[t]{4}{*}{ Water } & $\begin{array}{l}\text { Common } \\
\text { irrigation } \\
\text { water }\end{array}$ & 0.96 & 8.48 & 3.20 & 6.60 & 5.84 & 0.18 & 3.00 & 3.00 & 4.82 \\
\hline & Seawater & 44.00 & 7.44 & 26.77 & 67.01 & 400.85 & 9.07 & 427.16 & 2.98 & 73.56 \\
\hline & Mixed water & 4.56 & 8.24 & 4.60 & 12.60 & 33.77 & 1.37 & 38.00 & 4.40 & 9.94 \\
\hline & nixture & 1.37 & 7.55 & 1.80 & 2.00 & 8.10 & 1.80 & 11.90 & 1.80 & 0.00 \\
\hline
\end{tabular}




\subsection{Experimental Design and Treatments}

The hydroponic treatments were designed in a split-split plot design with three replicates. The sub-sub-plot factor was the pipe slope, the sub-plot factor was the depletion ratio and the main plot factor was the irrigation water type according to the experimental system. The experimental treatments included four types of irrigation water: common irrigation water $\left(\mathrm{IW}_{1}\right)$ having an EC of $0.96 \mathrm{dS} / \mathrm{m}$ which was used as the control treatment, magnetically treated canal irrigation water $\left(\mathrm{IW}_{2}\right)$ having an EC of $0.96 \mathrm{dS} / \mathrm{m}$, saline water $\left(\mathrm{IW}_{3}\right)$ having an EC of $4.56 \mathrm{dS} / \mathrm{m}$ and magnetically treated saline water $\left(\mathrm{IW}_{4}\right)$ having an EC of $4.56 \mathrm{dS} / \mathrm{m}$; three depletion ratios (DR) of irrigation water were applied $\left(\mathrm{DR}_{0}=50 \%\right.$ as control treatment, $\mathrm{DR}_{1}=60 \%$ and $\mathrm{DR}_{2}=70 \%$ ) as well as the three slopes (S) of the hydroponic piping system $\left(S_{1}=0 \%\right.$ as control treatment, $S_{2}=0.025 \%$ and $S_{3}=0.075 \%$ ). Three iceberg lettuce plants were randomly selected on each pipe to represent a replicate.

Prior to the main experiments, we tried to identify the threshold salinity level that the lettuce crop could cope with. As mentioned, the salinity of the common irrigation water and seawater was 0.96 and $34 \mathrm{dS} / \mathrm{m}$, respectively. The EC of the common irrigation water was below the threshold, and therefore it was essential to mix the fresh canal water and seawater at a ratio that the plants could tolerate. It was found from the pre-experiment that 13:1 common irrigation water/sea water is the ratio which produces an EC that lettuce plants can tolerate without magnetization. In addition, over the pre-experiments, it was noticed that using saline water of $4.56 \mathrm{dS} / \mathrm{m}$ without magnetization remarkably affected lettuce growth performance parameters. For example, the leaf edges and tips were changed to a yellowish color, and other problems were spotted in terms of the crop quality as a leafy crop, and thus the lettuce may be unmarketable in the case of using saline water without magnetization. Moreover, the seedlings were struggling to grow in such a high saline water. Common irrigation water can be used safely as the control treatment for growing lettuce, and thus it was used as the control.

\subsection{Nutrient Solution}

The concentrated nutrient solution was pre-prepared according to the schedule of the ICARDA for hydroponic farming systems. It contained essential elements which were added, by $5 \mathrm{~L}$ of solution $\mathrm{A}+5 \mathrm{~L}$ of solution $\mathrm{B}$, for each tank of $1000 \mathrm{~L}$ so to prepare a diluted solution, and it was preferable to move the solution before each irrigation event. Solution A contained a compound fertilizer of NPK ( $4.8 \mathrm{~kg} / 40 \mathrm{~L}$ of water), magnesium sulfate (1.6 kg/40 L of water) and micro-elements in MicroPlex (270/40 L of water), while solution B contained calcium nitrate $(7.6 \mathrm{~kg} / 40 \mathrm{~L}$ of water) and claw iron $(400 \mathrm{~g} / 40 \mathrm{~L}$ of water). Two water tanks were used for irrigation purposes, one for common irrigation water and the other for magnetically treated saline water.

\subsection{Total Soluble Solids (TSS)}

A refractometer was used to measure the TSS in iceberg lettuce leaves just prior the end of the experiment for the different treatments.

\subsection{Luminous Intensity}

The intensity of the lighting was regularly measured over the growing season using the lux meter. The lighting intensity was mainly recorded at 9:00 a.m., 11:00 a.m., 1:00 p.m. and 3:00 p.m. All readings were recorded and saved by the lux meter itself.

\subsection{Lettuce Yield}

The yield of iceberg lettuce was estimated based on the fresh weight in kilograms using a portable digital electronic scale of $0.01 \mathrm{~g}$ accuracy. 


\subsection{Irrigation Water Requirements and Scheduling}

Water requirements were computed for irrigating iceberg lettuce based on readily available water $(R A W)$, which was calculated according to the following formula by [43]:

$$
R A W=\frac{(M A D)\left(D_{r z}\right)\left(F_{C}-p w p\right)}{100}
$$

where, $R A W$ : readily available water $(\mathrm{cm}) ; M A D$ : maximum allowable deficiency or depletion ratio; $D_{r z}$ : depth of the root zone (assumed $10 \mathrm{~cm}$ ); $F_{C}$ : field capacity, \%; pwp: permanent wilting point, (\%). Based on the previous equation, the value of the $R A W$ was calculated, which was equal to an average of $6.457 \mathrm{~cm}$ for each irrigation event when the depletion ratio $\left(\mathrm{DR}_{0}\right)$ reached $50 \%$ from the field capacity of the soil mixture. The $R A W$ was $7.75 \mathrm{~cm}$ for each irrigation event at a $60 \%$ depletion ratio $\left(\mathrm{DR}_{1}\right)$. Moreover, the $R A W$ was $9.04 \mathrm{~cm}$ for each irrigation event at a $70 \%$ depletion ratio $\left(\mathrm{DR}_{2}\right)$. The moisture content of the soil mixture was monitored and calibrated by a time-domain reflectometer (TDR). The depletion ratio is not intended to reduce the water or deficit irrigation, but rather to add the same amounts of irrigation water; however, when $50 \%, 60 \%$ and $70 \%$ of it are exhausted, it is equal to $143.3 \%, 114.7 \%$, and $86 \%$ moisture content of the soil mixture, respectively. Therefore, the number of irrigation events was 13, 11 and 9, respectively, with an average of $6.18,7.29$ and $7.78 \mathrm{~L} / \mathrm{m}$ of pipe per one irrigation event, which is equivalent to an average of water applied of 1.52, 1.79 and $1.99 \mathrm{~L}$ per plant.

\subsection{Performance of Drip Irrigation System}

It is very important to apply irrigation water with a high-efficiency system, which should be evaluated prior conducting the experimental work. The distribution uniformity is among the most important efficiency indicators of drip systems, which was calculated according to [44].

$$
D U=\frac{q l q}{q^{-}} \times 100
$$

Where, DU: distribution uniformity, $\% ; q_{l q}$ : low quarter average amount caught; $q^{-}$: average amount caught. The obtained data demonstrated the high performance of the drip irrigation network used according to the ASAE (2001), where the mean value of DU was $97.51 \%$ [45].

\subsection{Water Productivity (WP)}

WP is the ratio between the total yield of lettuce and the amount of water applied to a certain treatment, which was calculated according to James [43] as follows:

$$
W P=\frac{\text { Totel yield, } \mathrm{kg} / \mathrm{m}}{\text { Totel applied irrigation water }, \mathrm{m}^{3} / \mathrm{m}}
$$

WP: water productivity $\left(\mathrm{kg} / \mathrm{m}^{3}\right)$.

\subsection{Statistical Analysis}

The effect of the different treatments on the TSS, the iceberg lettuce fresh weight and the water productivity was analyzed using the analysis of variance (ANOVA) technique in Statistix 9.0. The significant differences between the mean values of the three measured parameters for each cultivar were compared using Duncan's test at a $p \leq 0.05$ significance level. Moreover, collected data were analyzed and examined statistically by the least significant difference (LSD) test. 


\section{Results and Discussion}

3.1. Effect of Water Quality (Common Irrigation Water, Magnetically Treated Common Irrigation Water, Saline Water and Magnetically Treated Saline Water) on Total Soluble Solids, Fresh Weight and Water Productivity of Iceberg Lettuce

The effects of common irrigation water $\left(\mathrm{IW}_{1}\right)$, magnetically treated common irrigation water $\left(\mathrm{IW}_{2}\right)$, saline water $\left(\mathrm{IW}_{3}\right)$ and magnetically treated saline water $\left(\mathrm{IW}_{4}\right)$ on the total dissolved solids (TSS), the iceberg lettuce fresh weight and the water productivity of both iceberg lettuce cultivars is presented in Table 2. The results showed significant effects on various investigated crop parameters when subjected to the experimental treatments. The data showed that the $\mathrm{IW}_{4}$ treatments improved the TSS, the fresh weight of the lettuce crop and the water productivity for both studied cultivars. The maximum percentage and values of the TSS, fresh weight (FW) and water productivity (WP) were $4.46 \%, 2.64 \mathrm{~kg} / \mathrm{m}$ and $33.04 \mathrm{~kg} / \mathrm{m}^{3}$ for lemur, and $4.356,2.16 \mathrm{~kg} / \mathrm{m}$ and $26.37 \mathrm{~kg} / \mathrm{m}^{3}$ for lettuce 077 , respectively, which were recorded with the $\mathrm{IW}_{4}$ treatment. While the control treatment, $\mathrm{IW}_{1}$, produced values for the TSS, FW and WP of $3.58 \%, 1.94 \mathrm{~kg} / \mathrm{m}$ and $24.91 \mathrm{~kg} / \mathrm{m}^{3}$ for lemur and $3.48 \%$, $1.63 \mathrm{~kg} / \mathrm{m}$ and $20.17 \mathrm{~kg} / \mathrm{m}^{3}$ for 077 , respectively. The minimum values of $\mathrm{FW}$ and $W P$ were noticed with $\mathrm{IW}_{3}$. TSS, FW and WP increased by $24.6 \%, 36.1 \%$ and $32.6 \%$ with $\mathrm{IW}_{4}$, respectively, compared with the control treatment $\left(\mathrm{IW}_{1}\right.$ combination) for lemur iceberg lettuce. TSS, FW and WP increased by $32.5 \%, 25 \%$ and $30.7 \%$ with $\mathrm{IW}_{4}$, respectively, compared with the control treatment $\left(\mathrm{IW}_{1}\right)$. TSS, FW and WP increased by $24.6 \%, 36.1 \%$ and $32.6 \%$ with $\mathrm{IW}_{4}$, respectively, compared with the control treatment for lemur iceberg lettuce. TSS, FW and WP increased by $0.22 \%$ (non-significant), $140 \%$ and $139.07 \%$ with $\mathrm{IW}_{4}$, respectively, compared with the $\mathrm{IW}_{3}$ treatment for lemur iceberg lettuce. The same trends with iceberg lettuce 077 were also observed. The positive influence of $\mathrm{IW}_{4}$ may have been a result of changes in the water's physical properties (e.g., surface tension and viscosity), which may not affect the chemical characteristics of the water [26-28]. In general, increments could be due to the breaking down of the hydrogen bonds in the magnetized water molecules, resulting in smaller water molecules which influence the physical properties of the water, such as the viscosity and density. This allows water entry via plant cellular membranes and boosted water absorption, as well as potentially affecting the production of the hormone IAA, which improves plant cell activity and division. Surendran et al. [46] found that irrigation with magnetized water increased the soil moisture compared to the control, which might be attributed to two main reasons. Firstly, in the magnetization process, the water molecules which had been influenced by hydrogen bonds and Van der Waals forces were in reaction with the ions released to make the water more cohesive, and thus the water molecules were easily attached to the soil particles and did not leach to the lower depths; moreover, the water molecules easily penetrated into the micro-spaces of the soil particles and, consequently, were impeded from moving deeper. Secondly, when the water passes through the magnetized field, its structure and some of its physical characteristics will be changed. As calcium and carbonate ions enter into the zone that is influenced by the magnets, they are pushed in opposite directions, which is ascribable to their opposite charges. Additionally, Shukla et al. [27] discovered that a magnetic field can boost plant growth and nutrient content in a hydroponic farming system, proving that the magnetic field can produce superior results compared to traditional farming methods [27]. Moreover, according to Taimourya [28], magnetic treatment has a positive effect on mineral element uptakes such as $\mathrm{K}$ and $\mathrm{P}$, and when the nutrient solution is exposed to the magnetic field, the plant's roots are stimulated, allowing for higher nutrient absorption and improved plant characteristics. There were no significant effects of the magnetically treated common irrigation water $\left(\mathrm{IW}_{2}\right)$ on the TSS, FW or WP. 
Table 2. Effects of common irrigation water, magnetically treated common irrigation water, saline water and magnetically treated saline water on total soluble solids, fresh weight and water productivity of both investigated iceberg lettuce cultivars.

\begin{tabular}{|c|c|c|c|c|c|c|}
\hline \multirow{2}{*}{$\begin{array}{c}\text { Irrigation } \\
\text { Water Type }\end{array}$} & \multicolumn{2}{|c|}{ TSS, $\%$} & \multicolumn{2}{|c|}{ Fresh Weight, kg/m } & \multicolumn{2}{|c|}{ Water Productivity, $\mathrm{kg} / \mathrm{m}^{3}$} \\
\hline & Lemur & 077 & Lemur & 077 & Lemur & 077 \\
\hline $\mathrm{IW}_{1}$ & $3.58 \pm 0.223^{b}$ & $3.48 \pm 0.215^{\mathrm{b}}$ & $1.94 \pm 0.282^{c}$ & $1.63 \pm 0.279^{c}$ & $24.91 \pm 4.337^{b}$ & $20.17 \pm 3.680^{b}$ \\
\hline $\mathrm{IW}_{2}$ & $3.59 \pm 0.215^{b}$ & $3.48 \pm 0.211^{b}$ & $1.96 \pm 0.286^{b}$ & $1.64 \pm 0.279^{b}$ & $25.17 \pm 4.393^{b}$ & $20.31 \pm 3.679^{b}$ \\
\hline $\mathrm{IW}_{3}$ & $4.45 \pm 0.307^{\mathrm{a}}$ & $4.36 \pm 0.297^{\mathrm{a}}$ & $1.10 \pm 0.153^{\mathrm{d}}$ & $0.91 \pm 0.131^{\mathrm{d}}$ & $13.82 \pm 2.079^{c}$ & $11.08 \pm 1.658^{c}$ \\
\hline $\mathrm{IW}_{4}$ & $4.46 \pm 0.311^{\mathrm{a}}$ & $4.35 \pm 0.302^{\mathrm{a}}$ & $2.64 \pm 0.360^{a}$ & $2.16 \pm 0.315^{\mathrm{a}}$ & $33.04 \pm 4.866^{\mathrm{a}}$ & $26.37 \pm 4.080^{\mathrm{a}}$ \\
\hline F-VALUE & 1323.49 & 992.23 & $80,750.5$ & 162,157 & 5692.08 & 1174.75 \\
\hline F-TEST & $* * *$ & $* * *$ & $* * *$ & $* * *$ & $* * *$ & $* * *$ \\
\hline LSD 0.05 & 0.0490 & 0.0552 & $7.658 \times 10^{-03}$ & $4.425 \times 10^{-03}$ & 0.3625 & 0.6363 \\
\hline
\end{tabular}

The mean value of the three measured parameters within a certain column having the same letter are not significantly different from one another based on Duncan's multiple range test at a $p \leq 0.05$ significance level *** Indicates highly significant at $p \leq 0.001$ probability level. $\mathrm{W}_{1}, \mathrm{IW}_{2}, \mathrm{IW}_{3}$ and $\mathrm{IW}_{4}$ refer to common irrigation water, magnetically treated common irrigation, saline water and magnetically treated saline water, respectively.

\subsection{Effect of Depletion Ratio of Irrigation Water on Total Soluble Solids, Fresh Weight and Water Productivity of Iceberg Lettuce}

Table 3 presents the effect of the irrigation depletion ratio (DR) on the TSS, FW and WP of the two tested iceberg lettuce cultivars. The results demonstrated that the depletion ratio factor showed a highly significant impact on FW and WP, but there was no significant effect on the TSS. The results further showed that higher irrigation intervals at the depletion ratio $\left(\mathrm{DR}_{2}\right)$ improved the FW and WP of the lemur cultivar, with an average value of $2.10 \mathrm{~kg} / \mathrm{m}$ and $27.33 \mathrm{~kg} / \mathrm{m}^{3}$, respectively, which is equivalent to an increment of $25 \%$ and $31.14 \%$, respectively, compared with the depletion ratio $\mathrm{DR}_{0}$. For iceberg lettuce 077 , the greatest values of FW and WP of $1.71 \mathrm{~kg} / \mathrm{m}$ and $21.16 \mathrm{~kg} / \mathrm{m}^{3}$ were recorded with the depletion ratio $\left(\mathrm{DR}_{1}\right)$, which is equivalent to an increment of $19.6 \%$ and $21.2 \%$, respectively, compared with the depletion ratio $\mathrm{DR}_{1}$. The highest percentage of TSS was obtained at the depletion ratio $\left(\mathrm{DR}_{1}\right)$ for both lettuce cultivars, which was $4.04 \%$ for lemur and $3.94 \%$ for iceberg lettuce 077 , representing an increment of $0.75 \%$ and $0.77 \%$, respectively, compared with the depletion ratio $\mathrm{DR}_{0}$. The reason for this increase may be attributed to a greater opportunity for aerating the root zone of the lettuce, and also an increase in the amount of oxygen through the percentage of depletion of the soil mixture.

Table 3. Effect of depletion ratio on total soluble solids (TSS), fresh weight (FW) and water productivity $(W P)$ of iceberg lettuce.

\begin{tabular}{|c|c|c|c|c|c|c|}
\hline \multirow{2}{*}{$\begin{array}{c}\text { Depletion } \\
\text { Ratio }\end{array}$} & \multicolumn{2}{|c|}{ TSS, $\%$} & \multicolumn{2}{|c|}{ Fresh Weight, kg/m } & \multicolumn{2}{|c|}{ Water Productivity, kg/m ${ }^{3}$} \\
\hline & Lemur & 077 & Lemur & 077 & Lemur & 077 \\
\hline $\mathrm{DR}_{0}$ & $4.03 \pm 0.516^{b}$ & $3.91 \pm 0.510^{\mathrm{a}}$ & $1.68 \pm 0.498^{c}$ & $1.43 \pm 0.437^{c}$ & $20.84 \pm 6.242^{c}$ & $17.46 \pm 5.316^{c}$ \\
\hline $\mathrm{DR}_{1}$ & $4.06 \pm 0.369^{a}$ & $3.94 \pm 0.358^{\mathrm{a}}$ & $1.95 \pm 0.609^{b}$ & $1.71 \pm 0.587^{\mathrm{a}}$ & $24.54 \pm 7.624^{b}$ & $21.16 \pm 7.357^{\mathrm{a}}$ \\
\hline $\mathrm{DR}_{2}$ & $4.01 \pm 0.643^{\mathrm{ab}}$ & $3.92 \pm 0.629^{a}$ & $2.10 \pm 0.659^{a}$ & $1.62 \pm 0.487^{b}$ & $27.33 \pm 8.650^{\mathrm{a}}$ & $19.83 \pm 6.067^{b}$ \\
\hline F-VALUE & 3.36 & 2.58 & $12,864.4$ & $28,227.1$ & 202.60 & 232.01 \\
\hline F-TEST & ns & ns & $* * *$ & $* * *$ & $* * *$ & $* * *$ \\
\hline LSD 0.05 & 0.0379 & 0.0387 & $5.676 \times 10^{-03}$ & $2.553 \times 10^{-03}$ & 0.6852 & 0.3691 \\
\hline
\end{tabular}

The mean value of the three measured parameters within a certain column having the same letter are not significantly different from one another based on Duncan's multiple range test at a $p \leq 0.05$ significance level. ns and ${ }^{* * *}$ indicate non-significant and highly significant at $p \leq 0.001$ probability level, respectively. $\mathrm{DR}_{0}, \mathrm{DR}_{1}$ and $\mathrm{DR}_{2}$ refer to depletion ratio at $50 \%, 60 \%$ and $70 \%$, respectively.

\subsection{Effect of Pipe Slope on Total Soluble Solids, Fresh Weight and Water Productivity of Lettuce}

The effect of the pipe slope on the total soluble solids, fresh weight and water productivity of the two lettuce cultivars is shown in Table 4 . The pipe slope of the hydroponic system remarkably affected the measured crop parameters, since it significantly affected 
both the FW and WP of the lettuce, while there was no significant effect of the pipe slope on the TSS. The results further showed that the inclination of the pipes contributed to an increase in FW and WP. In the case of the lemur cultivar, the highest values of FW and WP were $2.09 \mathrm{~kg} / \mathrm{m}$ and $22.67 \mathrm{~kg} / \mathrm{m}^{3}$, representing an increase by $22.9 \%$ and $24.3 \%$, respectively, compared with the lowest value, which was recorded with $\mathrm{S}_{1}$. The highest fresh weight and water productivity values of $1.38 \mathrm{~kg} / \mathrm{m}$ and $22.67 \mathrm{~kg} / \mathrm{m}^{3}$ were recorded with $S_{3}$, which increased by $27.08 \%$ and $29.10 \%$, respectively, in comparison with the control. The maximum percentage of TSS of 4.1 and 4.01 for the lemur and 077 cultivars, respectively, were found with the slope $S_{2}$. This increase may be due to the difference in the luminous intensity on the inclination of the pipe. The maximum value of the luminous intensity was 22,330 lux recorded at 11:00 am with $\mathrm{S}_{3}$ (Figure 1), where the geometric shape represented as the slope of the pipes was remarkably influenced by the received luminous intensity. The improvements in the lettuce properties are related to the pipe slope, which directly affect the luminous intensity incident and which are among the most critical environmental parameters for crop physiology and biochemistry [47]. According to previous comparison research, the dry matter, leaves and whole plant, as well as the stomatal conductance, the photosynthetic rate and the stem diameter, decreased in low luminous intensity [48]. Increasing the pipe slopes from 0.0 to 0.025 and 0.075 increased the luminous intensity by $21 \%$ and $71 \%$, respectively, as correctshown in Figure 1 . The broadly zero slope produced less TSS, FW and WP for both tested cultivars.

Table 4. Effect of pipe slope on total soluble solids (TSS), fresh weight (FW) and water productivity $(W P)$ of both iceberg lettuce cultivars.

\begin{tabular}{|c|c|c|c|c|c|c|}
\hline \multirow{2}{*}{ Pipe Slope } & \multicolumn{2}{|c|}{ TSS, $\%$} & \multicolumn{2}{|c|}{ Fresh Weight, kg/m } & \multicolumn{2}{|c|}{ Water Productivity, kg/m ${ }^{3}$} \\
\hline & Lemur & 077 & Lemur & 077 & Lemur & 077 \\
\hline $\mathrm{S}_{1}$ & $3.95 \pm 0.578^{c}$ & $3.85 \pm 0.569^{c}$ & $1.70 \pm 0.580^{\mathrm{b}}$ & $1.44 \pm 0.422^{\mathrm{c}}$ & $21.66 \pm 7.352^{c}$ & $17.56 \pm 5.159^{c}$ \\
\hline $\mathrm{S}_{2}$ & $4.10 \pm 0.630^{\mathrm{a}}$ & $3.99 \pm 0.616^{\mathrm{a}}$ & $1.93 \pm 0.570^{\mathrm{ab}}$ & $1.48 \pm 0.471^{\mathrm{b}}$ & $24.13 \pm 7.240^{b}$ & $18.23 \pm 5.730^{\mathrm{ab}}$ \\
\hline $\mathrm{S}_{3}$ & $4.01 \pm 0.274^{b}$ & $3.91 \pm 0.269^{b}$ & $2.09 \pm 0.638^{a}$ & $1.83 \pm 0.568^{a}$ & $26.92 \pm 8.541^{\mathrm{a}}$ & $22.67 \pm 7.152^{\mathrm{a}}$ \\
\hline F-VALUE & 16.92 & 17.06 & 8941.73 & $31,758.5$ & 202.60 & 232.01 \\
\hline F-TEST & $* * *$ & $* * *$ & $* * *$ & $* * *$ & $* * *$ & $* * *$ \\
\hline LSD 0.05 & 0.0496 & 0.0476 & $5.907 \times 10^{-03}$ & $3.398 \times 10^{-03}$ & 0.5234 & 0.3056 \\
\hline
\end{tabular}

The mean value of the three measured parameters within a certain column having the same letter are not significantly different from one another based on Duncan's multiple range test at a $p \leq 0.05$ significance level. *** Indicates highly significant at $p \leq 0.001$ probability level. $S_{1}, S_{2}$ and $S_{3}$ refer to pipe slope at $0.000 \%, 0.025 \%$ and $0.075 \%$, respectively.

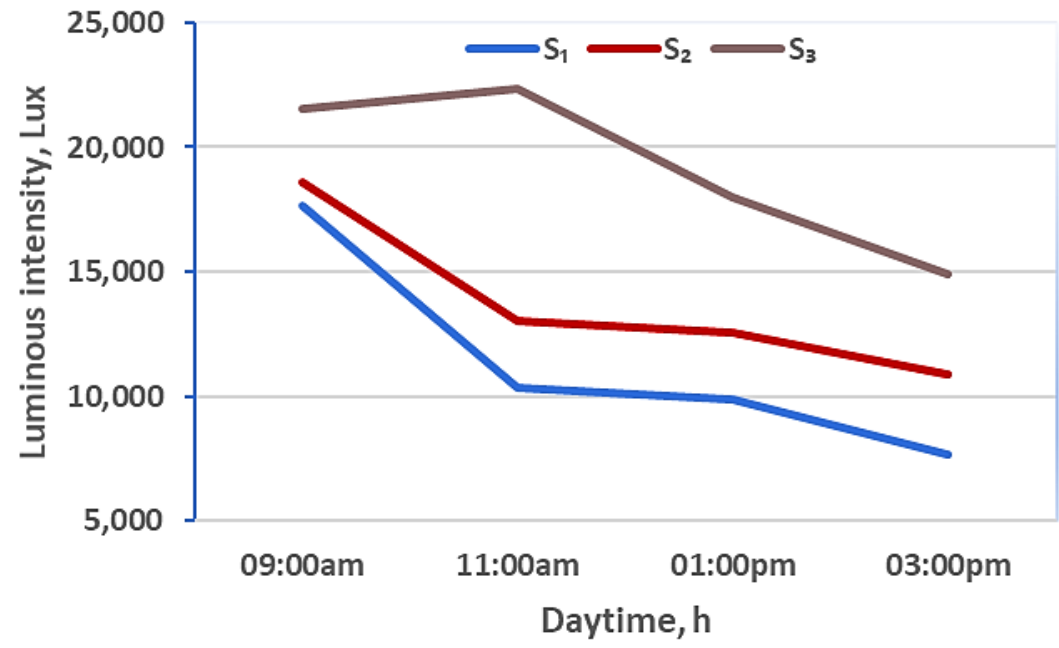

Figure 1. Luminous intensity recorded at different times throughout the day with different pipe slopes $\left(S_{1}, 0.000 \%\right.$ pipe slope; $S_{2}, 0.025 \%$ pipe slope; $S_{3}, 0.075 \%$ pipe slope). 
3.4. Interaction between Irrigation Water Type and Pipe Slope on Total Soluble Solids, Fresh Weight and Water Productivity of Lettuce

Figure 2 illustrates the interaction effect between the irrigation water type and the pipe slope on the TSS, FW and WP for the two cultivars of iceberg lettuce used. The statistical analysis showed that the interaction of both parameters had a significant effect on the TSS, since the highest percentages of $4.67 \%$ and $4.53 \%$ for lemur and 077 iceberg lettuce, respectively, were obtained with $S_{2}$. The results also demonstrated that the combinations $\mathrm{IW}_{4} \mathrm{~S}_{2}$ and $\mathrm{IW}_{3} \mathrm{~S}_{2}$ increased the TSS by $36.15 \%$ and $36.04 \%$ compared with $\mathrm{IW}_{1} \mathrm{~S}_{1}$ for the lemur and 077 cultivars, respectively. Consequently, there was a non-significant effect of the magnetically treated saline irrigation water on the TSS, which can be explained by some of the nutrients contained in saline water which improve the taste of the lettuce cultivars. In the case of using magnetically treated saline water $\left(\mathrm{IW}_{4}\right)$ for the lemur cultivar, the highest values reported for fresh weight and water productivity of $2.83 \mathrm{~kg} / \mathrm{m}$ and $35.06 \mathrm{~kg} / \mathrm{m}^{3}$, respectively, were recorded with $\mathrm{S}_{3}$. For the 077 cultivar, the highest values of fresh weight and water productivity of $2.43 \mathrm{~kg} / \mathrm{m}$ and $29.77 \mathrm{~kg} / \mathrm{m}^{3}$, respectively, were obtained from $S_{3}$. This increase could be attributed to the high luminous intensity. In comparison to $\mathrm{IW}_{1} \mathrm{~S}_{1}$ for the lemur and iceberg lettuce 077, IW $\mathrm{IW}_{3}$ increased the fresh weight by $73.26 \%$ and $76.08 \%$, respectively. In addition, the water productivity recorded with the $\mathrm{IW}_{4} \mathrm{~S}_{3}$ treatment increased by $65.69 \%$ and $74.71 \%$, respectively, compared to $\mathrm{IW}_{1} \mathrm{~S}_{1}$ for the lemur and iceberg lettuce 077 . The magnetically treated saline water perhaps helps to adjust the different physical water characteristics, including viscosity, surface tension and permeability, affecting the water pressure of osmosis, allowing the plant to increase its water uptake and improving its final production [49].

3.5. Interaction between Irrigation Water Type and Depletion Ratio on Total Soluble Solids, Fresh Weight and Water Productivity of Lettuce Varieties

Figure 3 presents the relationship between the irrigation water type and the depletion ratio on the TSS, fresh weight and water productivity of the two varieties of iceberg lettuce used. The statistical analysis showed that the interaction had a significant effect on all tested parameters. For the lemur and 077 cultivars, the highest TSS percentages of $4.57 \%$ and $4.46 \%$ were recorded with $\mathrm{IW}_{4} \mathrm{DR}_{2}$ and $\mathrm{IW}_{3} \mathrm{DR}_{2}$, respectively. The $\mathrm{IW}_{4} \mathrm{~S}_{3}$ treatment increased the TSS by $29.09 \%$ compared with the combination $\mathrm{IW}_{1} \mathrm{~S}_{1}$ for the two cultivars of iceberg lettuce. This increase may have been a result of some nutrients contained in saline water, and thus the magnetization had no significant effects on the TSS. The maximum values of lettuce fresh weight and water productivity were reported at $3.02 \mathrm{~kg} / \mathrm{m}$ and $38.11 \mathrm{~kg} / \mathrm{m}^{3}$, respectively, with $\mathrm{DR}_{2}$ and lemur iceberg lettuce, while the greatest respective values of fresh weight and water productivity for the 077 cultivar were $2.33 \mathrm{~kg} / \mathrm{m}$ and $28.39 \mathrm{~kg} / \mathrm{m}^{3}$, respectively, recorded with $\mathrm{DR}_{1}$. The fresh weight of lettuce increased with the combination $\mathrm{IW}_{4} \mathrm{DR}_{2}$ by $72.57 \%$ and $57.43 \%$ for the lemur and 077 cultivars, respectively, in comparison with the $\mathrm{IW}_{1} \mathrm{DR}_{0}$ treatment. The combinations $\mathrm{IW}_{4} \mathrm{DR}_{2}$ and $\mathrm{IW}_{2} \mathrm{DR}_{1}$ increased water productivity by $74.57 \%$ and $57.11 \%$ for the lemur and 077 cultivars, respectively, compared with the $\mathrm{IW}_{1} \mathrm{DR}_{0}$ treatment.

3.6. Interaction between Depletion Ratio and Pipe Slope on Total Soluble Solids, Fresh Weight and Water Productivity of Iceberg Lettuce

The interaction effect of the depletion ratio and the pipe slope on the TSS, fresh weight and water productivity of both investigated lettuce cultivars is depicted in Figure 4 . The statistical analysis reported that the interaction of both parameters had a significant effect on all tested crop properties. The highest percentage of TSS for the two cultivars of iceberg lettuce was recorded with $\mathrm{DR}_{2} \mathrm{~S}_{2}$, which was approximately $3.61 \%$ compared to $\mathrm{DR}_{0} \mathrm{~S}_{1}$. For fresh weight and water productivity, the highest values were $2.32 \mathrm{~kg} / \mathrm{m}$ and $31.08 \mathrm{~kg} / \mathrm{m}^{3}$, respectively, which were recorded with the combination $\mathrm{DR}_{2} \mathrm{~S}_{3}$ for the lemur cultivar. For the 077 cultivar, the combination $\mathrm{DR}_{1} \mathrm{~S}_{3}$ produced the highest values of fresh weight and water productivity of $2.09 \mathrm{~kg} / \mathrm{m}$ and $26.16 \mathrm{~kg} / \mathrm{m}^{3}$, respectively. Regarding the interaction between the depletion ratio and the pipe slope, the FW obtained from the combinations 
$\mathrm{DR}_{2} \mathrm{~S}_{3}$ and $\mathrm{DR}_{1} \mathrm{~S}_{3}$ increased by $55.7 \%$ and $47.18 \%$ for the lemur and iceberg lettuce 077 , respectively, compared to $\mathrm{DR}_{0} \mathrm{~S}_{1}$. $\mathrm{DR}_{2} \mathrm{~S}_{3}$ increased water productivity by $67.64 \%$ and $57.69 \%$ for the lemur and iceberg lettuce 077 , respectively, compared with $\mathrm{DR}_{0} \mathrm{~S}_{1}$.

\section{Lemur iceberg lettuce}

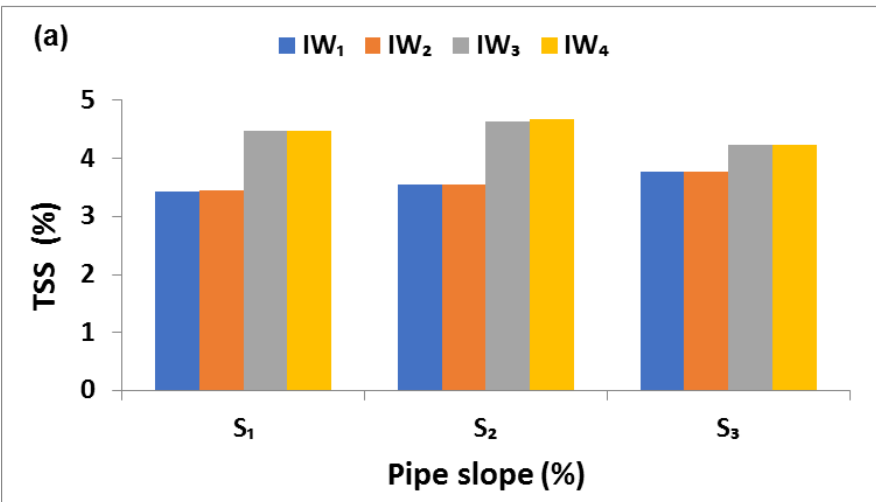

(b)
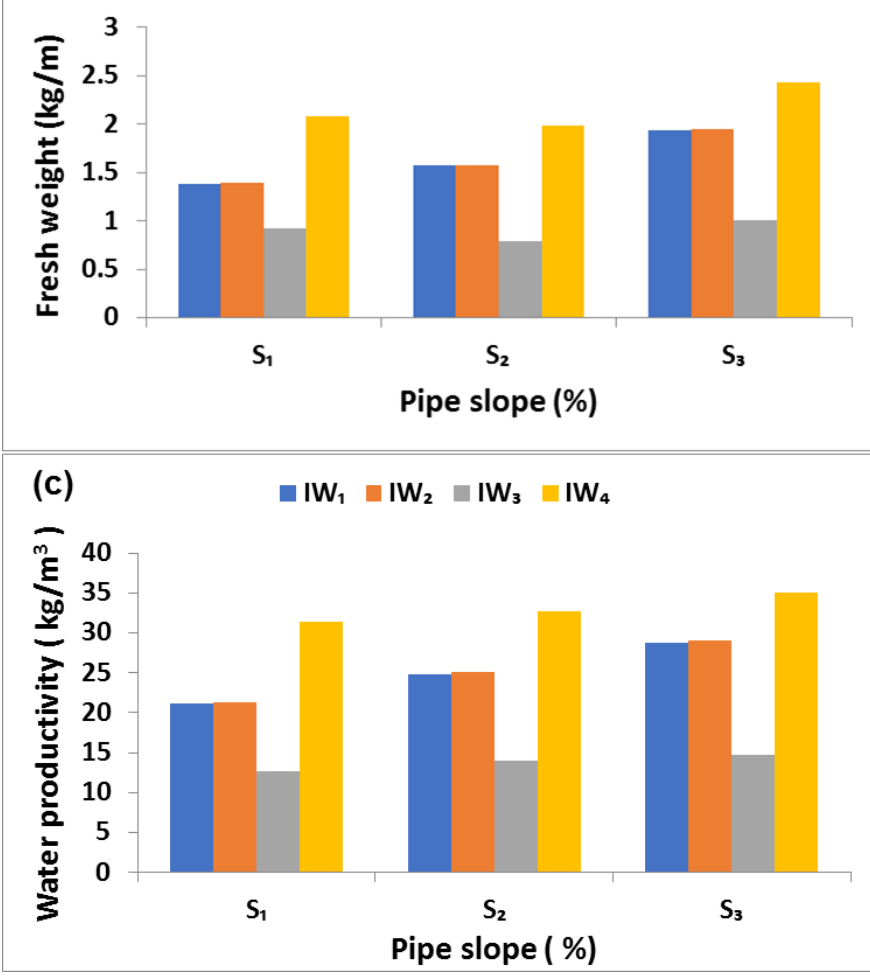

077 iceberg lettuce

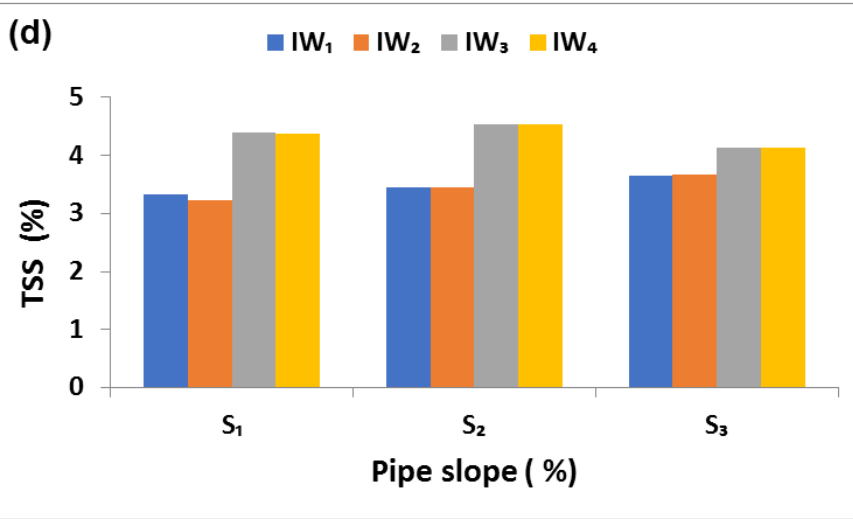

(e) $\quad \square I W_{1}=I W_{2} \square I W_{3} \varpi I W_{4}$
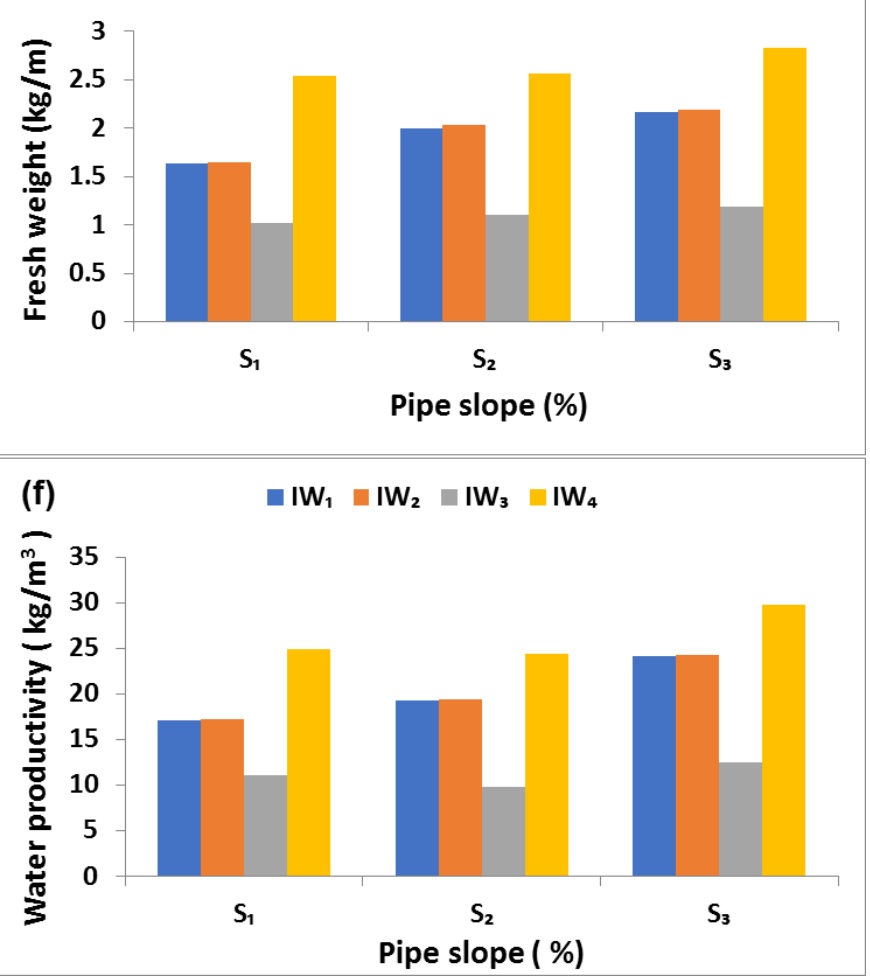

Figure 2. Interaction between irrigation water type and pipe slope on (a,d) total soluble solids (TSS), $(\mathbf{b}, \mathbf{e})$ fresh weight and (c,f) water productivity for lemur iceberg lettuce and 077 iceberg lettuce, respectively. $\mathrm{IW}_{1}$ refers to common irrigation water, $\mathrm{IW}_{2}$ represents magnetically treated common irrigation water, $\mathrm{IW}_{3}$ represents saline water and $\mathrm{IW}_{4}$ represents magnetically treated saline water. $\mathrm{S}_{1}, \mathrm{~S}_{2}$, and $\mathrm{S}_{3}$ refer to pipe slope at $0.000 \%, 0.025 \%$ and $0.075 \%$, respectively. 
Lemur iceberg lettuce

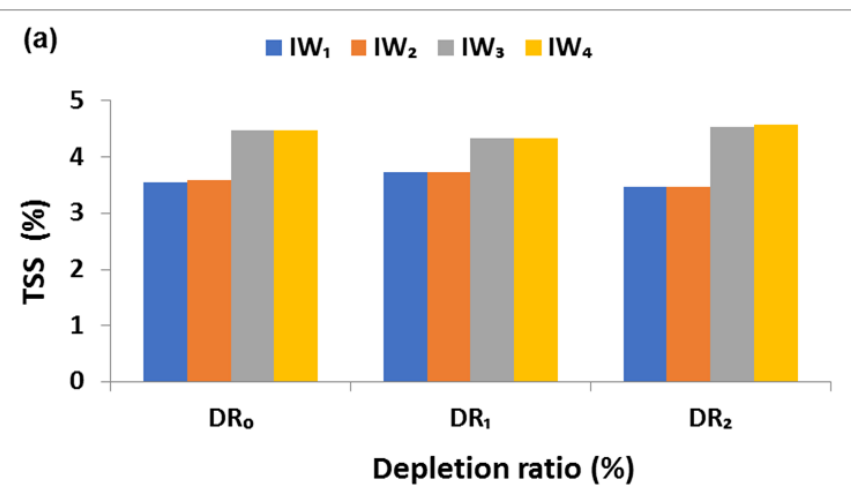

(b)
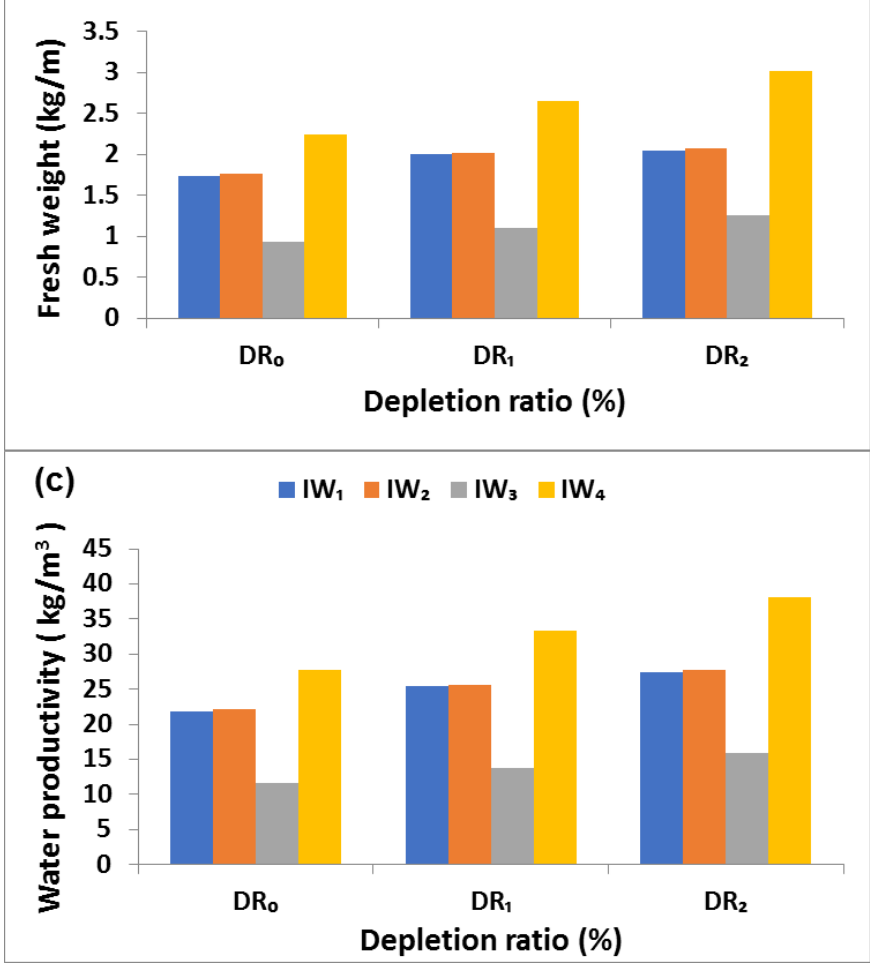

077 iceberg lettuce

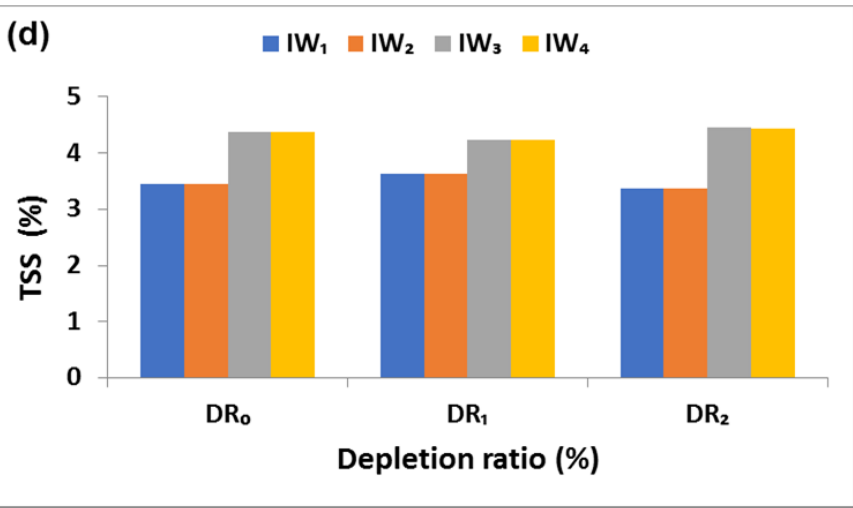

(e)

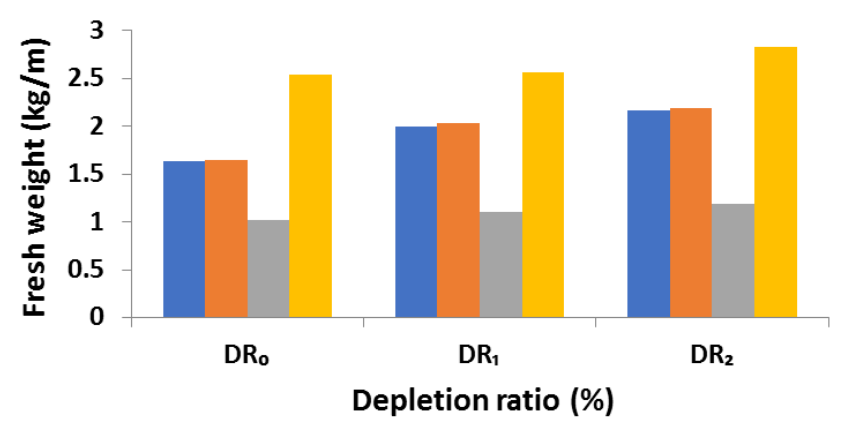

(f)

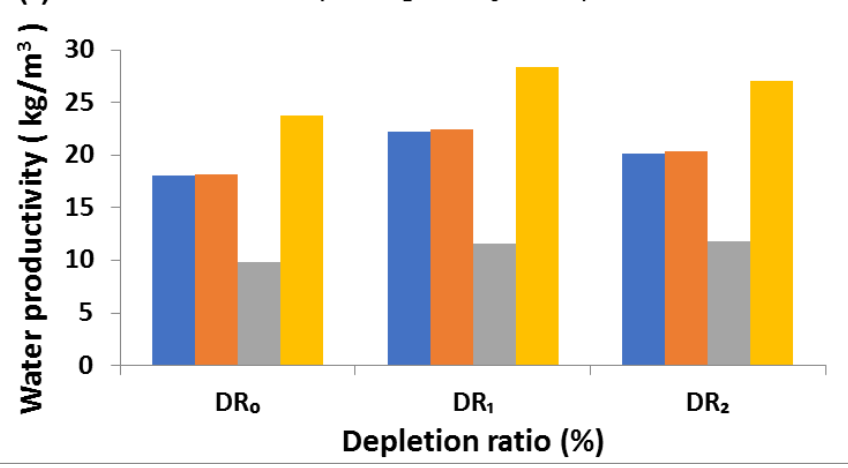

Figure 3. Interaction between irrigation water type and depletion ratio on $(\mathbf{a}, \mathbf{d})$ total soluble solids (TSS), (b,e) fresh weight and (c,f) water productivity of lemur and 077 cultivars, respectively. IW $_{1}$ refers to common irrigation water, $\mathrm{IW}_{2}$ represents magnetically treated common irrigation water, $\mathrm{IW}_{3}$ represents saline water and $\mathrm{IW}_{4}$ represents magnetically treated saline water. $\mathrm{DR}_{0}, \mathrm{DR}_{1}$ and $\mathrm{DR}_{2}$ represents the depletion ratio at $50 \%, 60 \%$ and $70 \%$, respectively.

3.7. Interaction among Irrigation Water Type, Depletion Ratio and Pipe Slope on Total Soluble Solids, Fresh Weight and Water Productivity of Both Iceberg Lettuce Cultivars

For both tested cultivars of iceberg lettuce, the effects of the interaction among the three parameters, including the irrigation water type, the depletion ratio and the pipe slope, are presented in Table 5. The statistical analysis showed that the interaction between the three tested factors significantly affected the total dissolved solids, fresh weight and water productivity of the lettuce. The maximum percentages of TSS were $5.20 \%$ and $5.00 \%$ for the lemur and 077 cultivars, respectively, which were recorded with the combination $\mathrm{IW}_{4} \mathrm{DR}_{2} \mathrm{~S}_{2}$, and thus increased the TSS by $48.57 \%$ relative to the control treatment $\left(\mathrm{IW}_{1} \mathrm{DR}_{0} \mathrm{~S}_{1}\right)$ for both iceberg lettuce cultivars. The highest values of lettuce fresh weight and water productivity of $3.10 \mathrm{~kg} / \mathrm{m}$ and $39.15 \mathrm{~kg} / \mathrm{m}^{3}$ were obtained from the combinations $\mathrm{IW}_{4} \mathrm{DR}_{2} \mathrm{~S}_{3}$ and 
$\mathrm{IW}_{4} \mathrm{DR}_{1} \mathrm{~S}_{3}$, with increments of $109.46 \%$ and $97.78 \%$, respectively, compared with the control treatment for the lemur cultivar. In the case of iceberg lettuce 077 , the greatest values of fresh weight and water productivity of $2.93 \mathrm{~kg} / \mathrm{m}$ and $36.15 \mathrm{~kg} / \mathrm{m}^{3}$ were obtained using $\mathrm{IW}_{4} \mathrm{DR}_{1} \mathrm{~S}_{3}$ with increments of $112.32 \%$ and $120.56 \%$, respectively, compared with the control treatment $\left(\mathrm{IW}_{1} \mathrm{DR}_{0} \mathrm{~S}_{1}\right)$. The combined effect of the water type, the hydroponic system geometry and the selected depletion ratios is a consequence of the increased test indicators.

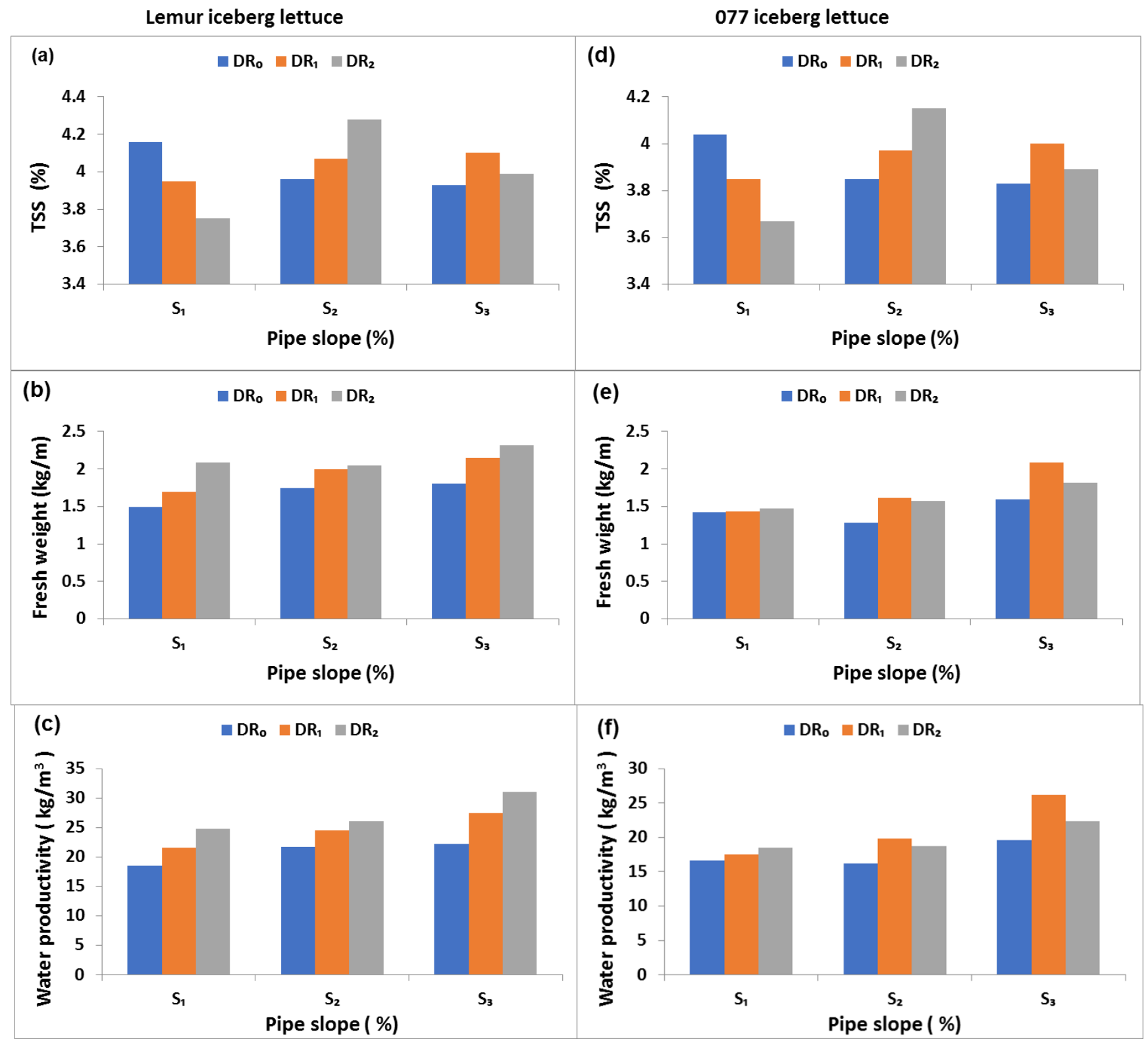

Figure 4. Interaction between pipe slope and depletion ratio on (a,d) total soluble solids (TSS), $(\mathbf{b}, \mathbf{e})$ fresh weight and (c,f) water productivity of lemur and 077 cultivars, respectively. $\mathrm{DR}_{0}, \mathrm{DR}_{1}$ and $\mathrm{DR}_{2}$ refer to depletion ratio at $50 \%, 60 \%$ and $70 \%$, respectively. $S_{1}, S_{2}$ and $S_{3}$ refer to pipe slope at $0.000 \%, 0.025 \%$ and $0.075 \%$, respectively. 
Table 5. Interaction among water type, depletion ratio and pipe slope on total soluble solids, fresh weight and water productivity of both investigated iceberg lettuce cultivars.

\begin{tabular}{|c|c|c|c|c|c|c|c|c|}
\hline \multicolumn{3}{|c|}{ Treatment } & \multicolumn{6}{|c|}{ Parameter } \\
\hline \multirow{2}{*}{$\begin{array}{l}\text { Irrigation } \\
\text { Water Type }\end{array}$} & \multirow{2}{*}{$\begin{array}{c}\text { Depletion } \\
\text { Ratio }\end{array}$} & \multirow{2}{*}{$\begin{array}{l}\text { Pipe } \\
\text { Slope }\end{array}$} & \multicolumn{2}{|c|}{ TSS, $\%$} & \multicolumn{2}{|c|}{ Fresh Weight, $\mathrm{kg} / \mathrm{m}$} & \multicolumn{2}{|c|}{ Water Productivity, $\mathrm{kg} / \mathrm{m}^{3}$} \\
\hline & & & Lemur & 077 & Lemur & 077 & Lemur & 077 \\
\hline $\mathrm{IW}_{1}$ & $\mathrm{DR}_{0}$ & $\mathrm{~S}_{1}$ & $3.50 \pm 0$ efg & $3.40 \pm 0^{\text {efg }}$ & $1.48 \pm 0.01 \mathrm{p}$ & $1.38 \pm 0.01^{\circ}$ & $18.93 \pm 0.22 \mathrm{kl}$ & $16.39 \pm 0.96^{j}$ \\
\hline $\mathrm{IW}_{1}$ & $\mathrm{DR}_{0}$ & $\mathrm{~S}_{2}$ & $3.50 \pm 0.21$ efg & $3.40 \pm 0.2$ efg & $1.86 \pm 0.01^{\mathrm{m}}$ & $1.36 \pm 0.03 \mathrm{p}$ & $22.48 \pm 2.15^{\mathrm{ij}}$ & $17.38 \pm 0.56^{\text {hij }}$ \\
\hline $\mathrm{IW}_{1}$ & $\mathrm{DR}_{0}$ & $\mathrm{~S}_{3}$ & $3.63 \pm 0.12$ ef & $3.53 \pm 0.12 e^{e f}$ & $1.90 \pm 0^{1}$ & $1.69 \pm 0.01^{\mathrm{k}}$ & $24.08 \pm 1.55 \mathrm{ghi}$ & $20.45 \pm 0.83 \mathrm{~g}$ \\
\hline $\mathrm{IW}_{1}$ & $\mathrm{DR}_{1}$ & $S_{1}$ & $3.50 \pm 0.21$ efg & $3.40 \pm 0.2^{\mathrm{efg}}$ & $1.62 \pm 0^{\circ}$ & $1.41 \pm 0.01^{\mathrm{n}}$ & $21.04 \pm 1.08^{\mathrm{jk}}$ & $17.79 \pm 0.16^{\text {hij }}$ \\
\hline $\mathrm{IW}_{1}$ & $\mathrm{DR}_{1}$ & $\mathrm{~S}_{2}$ & $3.73 \pm 0.16^{\mathrm{e}}$ & $3.63 \pm 0.15^{\mathrm{e}}$ & $2.19 \pm 0.01^{\mathrm{i}}$ & $1.78 \pm 0^{\mathrm{j}}$ & $26.58 \pm 1.01$ efg & $22.03 \pm 0.91{ }^{\text {ef }}$ \\
\hline $\mathrm{IW}_{1}$ & $\mathrm{DR}_{1}$ & $\mathrm{~S}_{3}$ & $3.97 \pm 0.06^{\mathrm{d}}$ & $3.87 \pm 0.06^{\mathrm{d}}$ & $2.21 \pm 0 \mathrm{hi}$ & $2.13 \pm 0^{\mathrm{d}}$ & $28.60 \pm 0.64$ de & $26.96 \pm 0.74^{b}$ \\
\hline $\mathrm{IW}_{1}$ & $\mathrm{DR}_{2}$ & $S_{1}$ & $3.30 \pm 0 \mathrm{~g}$ & $3.20 \pm 0 \mathrm{~g}$ & $1.80 \pm 0^{\mathrm{n}}$ & $1.34 \pm 0 \mathrm{q}$ & $23.52 \pm 1.06^{\text {hij }}$ & $16.94 \pm 0.78^{\mathrm{ij}}$ \\
\hline $\mathrm{IW}_{1}$ & $\mathrm{DR}_{2}$ & $\mathrm{~S}_{2}$ & $3.40 \pm 0.10^{\mathrm{fg}}$ & $3.30 \pm 0.1 \mathrm{fg}$ & $1.96 \pm 0.01^{\mathrm{k}}$ & $1.59 \pm 0^{1}$ & $25.17 \pm 0.55$ fghi & $18.54 \pm 0.49 \mathrm{hi}$ \\
\hline $\mathrm{IW}_{1}$ & $\mathrm{DR}_{2}$ & $\mathrm{~S}_{3}$ & $3.70 \pm 0^{\mathrm{e}}$ & $3.57 \pm 0.06^{\text {ef }}$ & $2.40 \pm 0^{f}$ & $1.99 \pm 0.01^{\mathrm{h}}$ & $33.78 \pm 1.4^{\mathrm{b}}$ & $25.08 \pm 0.09^{c}$ \\
\hline $\mathrm{IW}_{2}$ & $\mathrm{DR}_{0}$ & $S_{1}$ & $3.53 \pm 0.06^{\text {efg }}$ & $3.37 \pm 0.06^{\text {efg }}$ & $1.49 \pm 0.01 \mathrm{p}$ & $1.39 \pm 0.01^{\circ}$ & $19.06 \pm 0.17^{\mathrm{kl}}$ & $16.54 \pm 1.01^{j}$ \\
\hline $\mathrm{IW}_{2}$ & $\mathrm{DR}_{0}$ & $\mathrm{~S}_{2}$ & $3.53 \pm 0.12$ efg & $3.40 \pm 0$ efg & $1.90 \pm 0.06^{1}$ & $1.36 \pm 0.01 \mathrm{p}$ & $23.01 \pm 2.69$ hij & $17.38 \pm 0.57$ hij \\
\hline $\mathrm{IW}_{2}$ & $\mathrm{DR}_{0}$ & $\mathrm{~S}_{3}$ & $3.70 \pm 0^{\mathrm{e}}$ & $3.57 \pm 0.06^{\text {ef }}$ & $1.92 \pm 0.01^{1}$ & $1.70 \pm 0^{\mathrm{k}}$ & 24.341.59 fghi & $20.58 \pm 0.8^{g}$ \\
\hline $\mathrm{IW}_{2}$ & $\mathrm{DR}_{1}$ & $\mathrm{~S}_{1}$ & $3.50 \pm 0.21$ efg & $3.40 \pm 0.2^{\text {efg }}$ & $1.64 \pm 0.01^{\circ}$ & $1.43 \pm 0^{\mathrm{m}}$ & $21.29 \pm 1.13^{j k}$ & $18.00 \pm 0.1^{\text {hij }}$ \\
\hline $\mathrm{IW}_{2}$ & $\mathrm{DR}_{1}$ & $\mathrm{~S}_{2}$ & $3.73 \pm 0.16^{\mathrm{e}}$ & $3.63 \pm 0.15^{\mathrm{e}}$ & $2.22 \pm 0.02 \mathrm{hi}$ & $1.79 \pm 0^{\mathrm{i}}$ & $26.93 \pm 1.07^{e f}$ & $22.21 \pm 0.93 \mathrm{ef}$ \\
\hline $\mathrm{IW}_{2}$ & $\mathrm{DR}_{1}$ & $\mathrm{~S}_{3}$ & $3.97 \pm 0.06^{\mathrm{d}}$ & $3.87 \pm 0.0 .6^{\mathrm{d}}$ & $2.22 \pm 0.01 \mathrm{hi}$ & $2.14 \pm 0^{\mathrm{d}}$ & $28.73 \pm 0.62 \mathrm{de}$ & $27.05 \pm 0.77^{b}$ \\
\hline $\mathrm{IW}_{2}$ & $\mathrm{DR}_{2}$ & $\mathrm{~S}_{1}$ & $3.30 \pm 0 \mathrm{~g}$ & $3.20 \pm 0^{g}$ & $1.81 \pm 0^{\mathrm{n}}$ & $1.36 \pm 0 \mathrm{p}$ & $23.68 \pm 1.09$ hij & $17.16 \pm 0.79$ hij \\
\hline $\mathrm{IW}_{2}$ & $\mathrm{DR}_{2}$ & $\mathrm{~S}_{2}$ & $3.40 \pm 0.1^{\mathrm{fg}}$ & $3.30 \pm 0.1 \mathrm{fg}$ & $1.97 \pm 0.01^{\mathrm{k}}$ & $1.60 \pm 0^{1}$ & $25.38 \pm 0.6^{\mathrm{fgh}}$ & $18.63 \pm 0.52^{h}$ \\
\hline $\mathrm{IW}_{2}$ & $\mathrm{DR}_{2}$ & $\mathrm{~S}_{3}$ & $3.67 \pm 0.06^{\mathrm{ef}}$ & $3.60 \pm 0^{\mathrm{e}}$ & $2.43 \pm 0 \mathrm{e}^{\mathrm{e}}$ & $2.00 \pm 0 \mathrm{~g}$ & $34.15 \pm 1.46^{b}$ & $25.25 \pm 0.01^{\mathrm{c}}$ \\
\hline $\mathrm{IW}_{3}$ & $\mathrm{DR}_{0}$ & $S_{1}$ & $4.80 \pm 0.1^{b}$ & $4.70 \pm 0.1^{b}$ & $0.85 \pm 0^{w}$ & $0.89 \pm 0^{\mathrm{u}}$ & $10.34 \pm 0.44^{q}$ & $10.22 \pm 0.1^{\mathrm{m}}$ \\
\hline $\mathrm{IW}_{3}$ & $\mathrm{DR}_{0}$ & $\mathrm{~S}_{2}$ & $4.40 \pm 0.1^{\mathrm{c}}$ & $4.30 \pm 0.1^{c}$ & $0.98 \pm 0^{\mathrm{v}}$ & $0.70 \pm 0^{x}$ & $12.66 \pm 0.45^{\mathrm{op}}$ & $8.78 \pm 0.18^{n}$ \\
\hline $\mathrm{IW}_{3}$ & $\mathrm{DR}_{0}$ & $\mathrm{~S}_{3}$ & $4.20 \pm 0.11^{\mathrm{cd}}$ & $4.10 \pm 0.1^{\mathrm{cd}}$ & $1.00 \pm 0^{\mathrm{uv}}$ & $0.85 \pm 0^{\mathrm{v}}$ & $12.00 \pm 0.57 \mathrm{pq}$ & $10.61 \pm 0.24 \mathrm{~m}$ \\
\hline $\mathrm{IW}_{3}$ & $\mathrm{DR}_{1}$ & $\mathrm{~S}_{1}$ & $4.40 \pm 0.1^{c}$ & $4.30 \pm 0.1^{c}$ & $1.02 \pm 0^{\mathrm{u}}$ & $0.88 \pm 0^{\mathrm{u}}$ & $12.83 \pm 0.2 \mathrm{op}$ & $10.52 \pm 0.6^{\mathrm{m}}$ \\
\hline $\mathrm{IW}_{3}$ & $\mathrm{DR}_{1}$ & $\mathrm{~S}_{2}$ & $4.40 \pm 0.1^{c}$ & $4.30 \pm 0.1^{c}$ & $1.09 \pm 0^{t}$ & $0.80 \pm 0 \mathrm{w}$ & $13.69 \pm 1.2^{\text {nop }}$ & $9.79 \pm 0.42 \mathrm{mn}$ \\
\hline $\mathrm{IW}_{3}$ & $\mathrm{DR}_{1}$ & $\mathrm{~S}_{3}$ & $4.23 \pm 0.06^{c}$ & $4.13 \pm 0.06^{c}$ & $1.20 \pm 0^{\mathrm{s}}$ & $1.17 \pm 0^{\mathrm{r}}$ & $14.98 \pm 0.15^{\mathrm{mno}}$ & $14.46 \pm 0.29 \mathrm{k}$ \\
\hline $\mathrm{IW}_{3}$ & $\mathrm{DR}_{2}$ & $\mathrm{~S}_{1}$ & $4.20 \pm 0.01^{\mathrm{cd}}$ & $4.17 \pm 0.05^{c}$ & $1.18 \pm 0^{s}$ & $0.99 \pm 0^{t}$ & $14.87 \pm 0.35^{\mathrm{mno}}$ & $12.43 \pm 0.25^{1}$ \\
\hline $\mathrm{IW}_{3}$ & $\mathrm{DR}_{2}$ & $\mathrm{~S}_{2}$ & $5.10 \pm 0^{a}$ & $5.00 \pm 0^{\mathrm{a}}$ & $1.25 \pm 0^{\mathrm{r}}$ & $0.88 \pm 0^{\mathrm{u}}$ & $15.78 \pm 0.48^{\mathrm{mn}}$ & $10.70 \pm 0.44^{\mathrm{m}}$ \\
\hline $\mathrm{IW}_{3}$ & $\mathrm{DR}_{2}$ & $\mathrm{~S}_{3}$ & $4.30 \pm 0^{c}$ & $4.20 \pm 0^{\mathrm{c}}$ & $1.36 \pm 0 \mathrm{q}$ & $1.02 \pm 0^{\mathrm{s}}$ & $17.23 \pm 0.39 \mathrm{~lm}$ & $12.25 \pm 0.59^{1}$ \\
\hline $\mathrm{IW}_{4}$ & $\mathrm{DR}_{0}$ & $\mathrm{~S}_{1}$ & $4.80 \pm 0.1^{b}$ & $4.70 \pm 0.1^{\mathrm{b}}$ & $2.13 \pm 0.01^{\mathrm{j}}$ & $2.02 \pm 0^{\mathrm{f}}$ & $25.84 \pm 1.09 \mathrm{fgh}$ & $23.24 \pm 0.23 \mathrm{de}$ \\
\hline $\mathrm{IW}_{4}$ & $\mathrm{DR}_{0}$ & $\mathrm{~S}_{2}$ & $4.40 \pm 0.1^{\mathrm{c}}$ & $4.30 \pm 0.1^{\mathrm{c}}$ & $2.23 \pm 0.01^{\mathrm{h}}$ & $1.70 \pm 0.01^{\mathrm{k}}$ & $28.78 \pm 1.02 \mathrm{de}$ & $21.42 \pm 0.44^{\mathrm{fg}}$ \\
\hline $\mathrm{IW}_{4}$ & $\mathrm{DR}_{0}$ & $\mathrm{~S}_{3}$ & $4.20 \pm 0.1^{\mathrm{cd}}$ & $4.10 \pm 0.1^{\mathrm{cd}}$ & $2.38 \pm 0^{g}$ & $2.13 \pm 0.01^{\mathrm{d}}$ & $28.58 \pm 1.35 \mathrm{de}$ & $26.54 \pm 0.6^{b}$ \\
\hline $\mathrm{IW}_{4}$ & $\mathrm{DR}_{1}$ & $\mathrm{~S}_{1}$ & $4.40 \pm 0.1^{\mathrm{c}}$ & $4.30 \pm 0.1^{\mathrm{c}}$ & $2.48 \pm 0^{\mathrm{d}}$ & $2.01 \pm 0 \mathrm{~g}$ & $31.30 \pm 0.48^{c}$ & $23.90 \pm 1.37^{\mathrm{cd}}$ \\
\hline $\mathrm{IW}_{4}$ & $\mathrm{DR}_{1}$ & $\mathrm{~S}_{2}$ & $4.40 \pm 0.1^{\mathrm{c}}$ & $4.30 \pm 0.1^{c}$ & $2.49 \pm 0.01^{\mathrm{d}}$ & $2.06 \pm 0^{\mathrm{e}}$ & $31.10 \pm 2.73^{\mathrm{cd}}$ & $25.11 \pm 1.08^{c}$ \\
\hline $\mathrm{IW}_{4}$ & $\mathrm{DR}_{1}$ & $\mathrm{~S}_{3}$ & $4.23 \pm 0.06^{c}$ & $4.13 \pm 0.06^{c}$ & $3.00 \pm 0.01^{b}$ & $2.93 \pm 0^{a}$ & $37.44 \pm 0.39^{a}$ & $36.15 \pm 0.74^{\mathrm{a}}$ \\
\hline $\mathrm{IW}_{4}$ & $\mathrm{DR}_{2}$ & $\mathrm{~S}_{1}$ & $4.20 \pm 0.1^{\mathrm{cd}}$ & $4.10 \pm 0.1^{\mathrm{cd}}$ & $2.94 \pm 0.01^{c}$ & $2.20 \pm 0^{\mathrm{c}}$ & $37.18 \pm 0.88^{a}$ & $27.62 \pm 0.55^{b}$ \\
\hline $\mathrm{IW}_{4}$ & $\mathrm{DR}_{2}$ & $\mathrm{~S}_{2}$ & $5.20 \pm 0.1^{\mathrm{a}}$ & $5.00 \pm 0^{\mathrm{a}}$ & $3.01 \pm 0^{\mathrm{b}}$ & $2.21 \pm 0^{\mathrm{c}}$ & $38.01 \pm 1.17^{\mathrm{a}}$ & $26.75 \pm 1.09^{b}$ \\
\hline $\mathrm{IW}_{4}$ & $\mathrm{DR}_{2}$ & $\mathrm{~S}_{3}$ & $4.30 \pm 0^{c}$ & $4.20 \pm 0^{c}$ & $3.10 \pm 0^{\mathrm{a}}$ & $2.22 \pm 0^{b}$ & $39.15 \pm 0.88^{a}$ & $26.62 \pm 1.28^{b}$ \\
\hline & F-VALUE & & 10.43 & 10.50 & 227.23 & 890.26 & 5.95 & 23.14 \\
\hline & F-TEST & & $* * *$ & $* * *$ & $* * *$ & $* * *$ & $* * *$ & $* * *$ \\
\hline & LSD 0.05 & & 0.167 & 0.167 & 0.021 & 0.013 & 1.813 & 1.058 \\
\hline
\end{tabular}

The mean value of the three measured parameters within a certain column having the same letter are not significantly different from one another based on Duncan's multiple range test at a $p \leq 0.05$ significance level *** Indicates highly significant at $p \leq 0.001$ probability level. $\mathrm{IW}_{1}, \mathrm{IW}_{2}, \mathrm{IW}_{3}$ and $\mathrm{IW}_{4}$ refer to common irrigation water, magnetically treated common irrigation water, non-magnetically treated saline water and magnetically treated saline water, respectively. $\mathrm{DR}_{0}, \mathrm{DR}_{1}$, and $\mathrm{DR}_{2}$ represent $50 \%, 60 \%$ and $70 \%$ depletion ratio, respectively. $\mathrm{S}_{1}, \mathrm{~S}_{2}$ and $\mathrm{S}_{3}$ represent the pipe slope at $0.000-0.025 \%$ and $0.075 \%$, respectively.

\section{Conclusions}

This research study aimed to maximize the yield and water productivity of lettuce crop using magnetically treated saline water in a hydroponic farming system. The soilless cultivation system, especially hydroponic and vertical cultivation, is considered a viable alternative for traditional horizontal growth systems by optimizing more efficient use of any space, thus producing more crops per unit area. Further maximization in yield and water productivity can be achieved through these systems. There is a beneficial effect of magnetically treated saline water on fresh weight, yield and water productivity of iceberg lettuce. Thus, it can be a promising solution for water scarcity problems. Magnetic treatment, depletion ratio and pipe slope had significant effects on lettuce properties. The maximum percentages of TSS were $5.20 \%$ and $5.10 \%$ for the lemur and 077 cultivars, respec- 
tively, which were recorded with the combination $I_{4} \mathrm{DR}_{2} \mathrm{~S}_{2}$. The highest values of lettuce fresh weight and water productivity of $3.10 \mathrm{~kg} / \mathrm{m}$ and $39.15 \mathrm{~kg} / \mathrm{m}^{3}$ were obtained from the combinations $\mathrm{IW}_{4} \mathrm{DR}_{2} \mathrm{~S}_{3}$ and $\mathrm{IW}_{4} \mathrm{DR}_{1} \mathrm{~S}_{3}$, respectively. The fixed magnetic irrigation water technology does not pollute the environment and is currently inexpensive. The results demonstrated that using saline water to irrigate lettuce without magnetic treatment reduced the fresh yield by 55\% to $60 \%$. The magnetic treatment of common irrigation water did not have a significant effect on the lettuce fresh weight when using common irrigation water. The future challenges of water scarcity, deterioration of water quality and the increasing salinity of possible irrigation water resources associated with rapid population growth are among the main limiting factors for food production in many areas worldwide, especially in arid and semi-arid environments. In this regard, potential future directions are to use different technologies and highly saline water in irrigation to produce food to meet the needs of the population. One of these solutions is the use of soilless hydroponics and the magnetic treatment of water. Our future studies will focus on using different magnetic field strengths, directions and cycle numbers of magnetic and different types of alternative soils. In conclusion, a combined approach of using magnetically treated low quality water along with hydroponic farming systems can be a reliable technique to sustain a rapidly growing population in many regions worldwide suffering from scarcity of water.

Author Contributions: Conceptualization, A.M.O., A.H.E. and Z.M.Y.; data curation, Z.M.Y. and S.E.; formal analysis, A.M.O., E.M.E., A.H.E., A.A.F., Z.M.Y. and S.E.; investigation, A.M.O., E.M.E., A.H.E., A.A.F., Z.M.Y. and S.E.; methodology, E.M.E. and A.H.E.; resources, A.H.E.; supervision, A.A.F. and Z.M.Y.; validation, E.M.E., A.A.F. and S.E.; visualization, Z.M.Y. and S.E.; writing-original draft, A.M.O., E.M.E., A.H.E., A.A.F., Z.M.Y. and S.E.; writing-review and editing, A.M.O., A.A.F., Z.M.Y. and S.E. All authors have read and agreed to the published version of the manuscript.

Funding: This research received no external funding.

Data Availability Statement: Data are presented in the article.

Acknowledgments: The authors thanks and acknowledge the assistance and consultation for our reported study by Said Mohamed Khalifa, Agricultural Engineering Department, Faculty of Agriculture, Kafrelsheikh University.

Conflicts of Interest: The authors declare no conflict of interest.

\section{Appendix A}

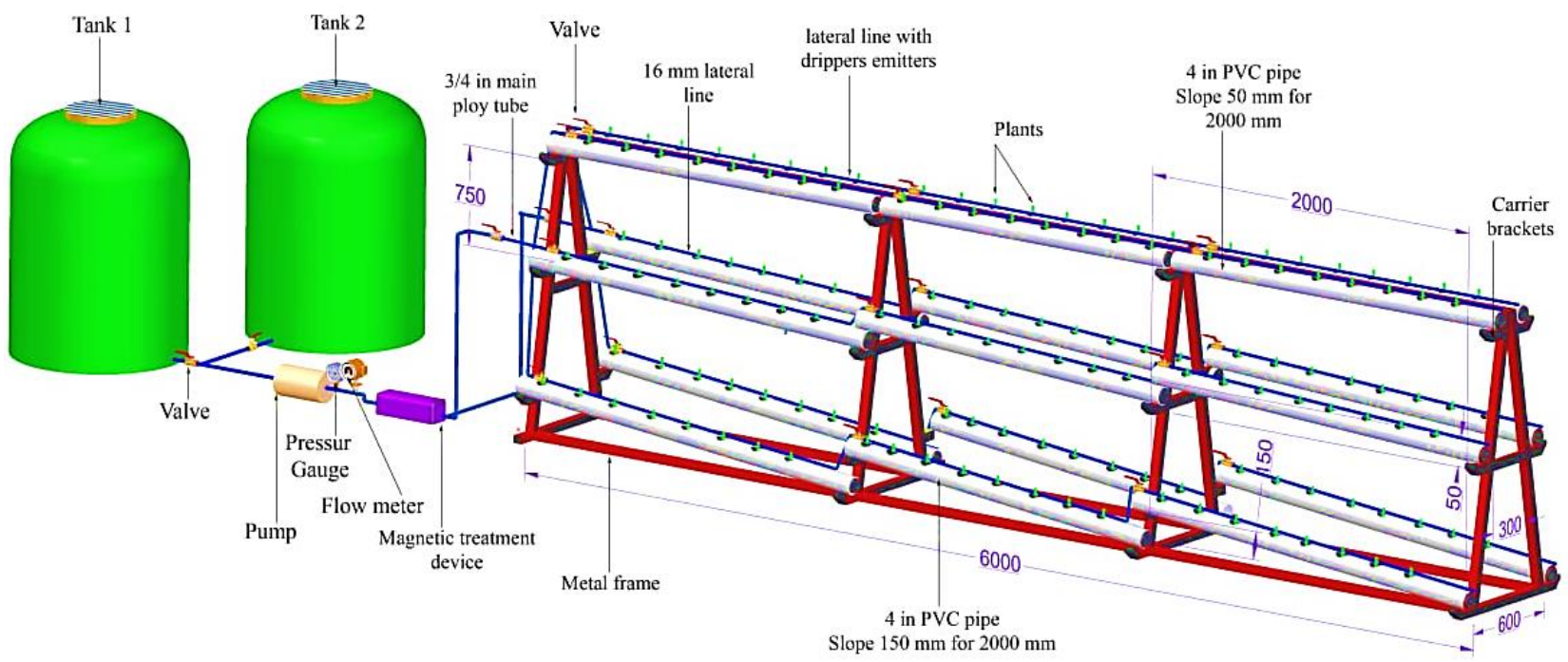

Figure A1. Engineering drawing and set-up showing the experimental hydroponic farming system with magnetic device. 


\section{Appendix B}

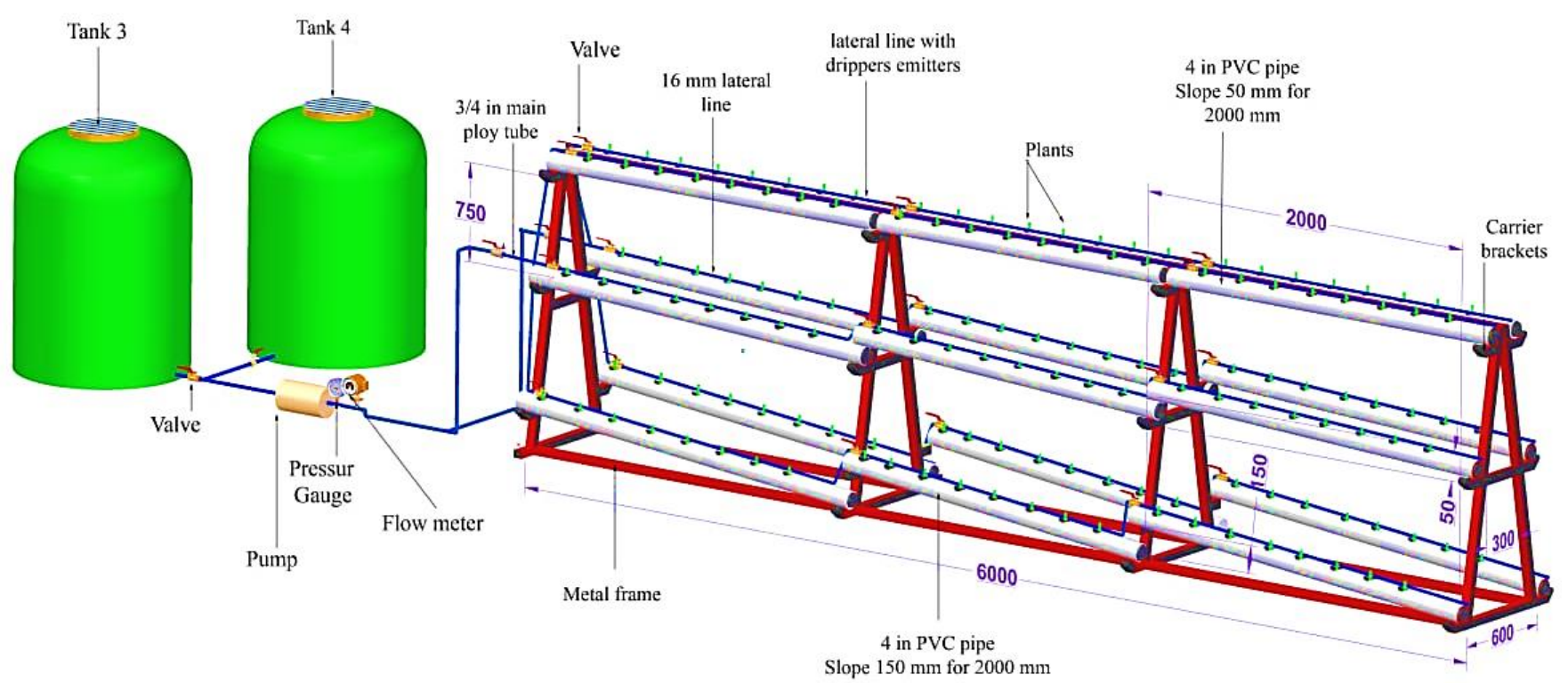

Figure A2. Engineering drawing and set-up showing the experimental hydroponic farming system without magnetic device.

\section{Appendix C}

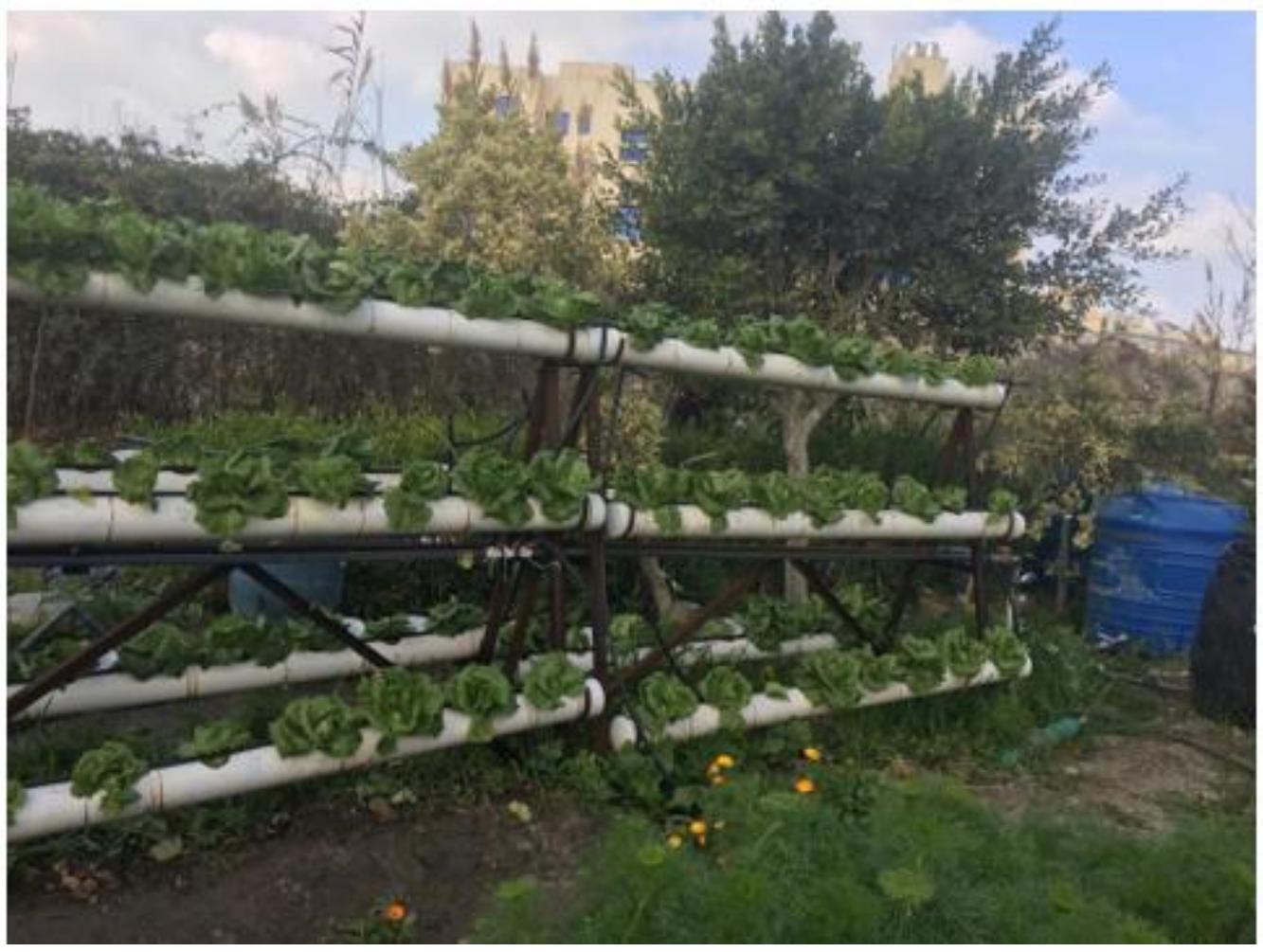

Figure A3. The experimental hydroponic farming system. 


\section{References}

1. Ali, R.R. Geomatics based soil mapping and degradation risk assessment of the cultivated land in El-Fayoum Depression, Egypt. Egypt. J. Soil Sci. 2005, 45, 349.

2. Khater, A.; Kitamura, Y.; Shimizu, K.; Abou El Hassan, W.; Fujimaki, H. Quantitative analysis of reusing agricultural water to compensate for water supply deficiencies in the Nile Delta irrigation network. Paddy Water Environ. 2015, 13, 367-378. [CrossRef]

3. El-Hendawy, S.E.; Schmidhalter, U. Optimal coupling combinations between irrigation frequency and rate for drip-irrigated maize grown on sandy soil. Agric. Water Manag. 2010, 97, 439-448. [CrossRef]

4. Chartzoulakis, K.; Bertaki, M. Sustainable Water Management in Agriculture under Climate Change. Agric. Agric. Sci. Procedia 2015, 4, 88-98. [CrossRef]

5. Canton, H. Food and Agriculture Organization of the United Nations-FAO. In The Europa Directory of International Organizations 2021; Routledge: Abingdon, UK, 2021; pp. 297-305. ISBN 1003179908.

6. $\quad$ Elmetwalli, A.H.; El-Hendawy, S.; Al-Suhaibani, N.; Alotaibi, M.; Tahir, M.U.; Mubushar, M.; Hassan, W.M.; Elsayed, S. Potential of Hyperspectral and Thermal Proximal Sensing for Estimating Growth Performance and Yield of Soybean Exposed to Different Drip Irrigation Regimes Under Arid Conditions. Sensors 2020, 20, 6569. [CrossRef] [PubMed]

7. Walters, K.J.; Currey, C.J. Hydroponic Greenhouse Basil Production: Comparing Systems and Cultivars. Horttechnology 2015, 25, 645-650. [CrossRef]

8. Asaduzzaman, M.; Talukder, M.R.; Tanaka, H.; Ueno, M.; Kawaguchi, M.; Yano, S.; Ban, T.; Asao, T. Production of Low-Potassium Content Melon Through Hydroponic Nutrient Management Using Perlite Substrate. Front. Plant Sci. 2018, 9, 1382. [CrossRef] [PubMed]

9. Mattson, N.; Lieth, J.H. Liquid Culture Hydroponic System Operation. Soil. Cult. 2019, 567-585. [CrossRef]

10. Levine, C.P.; Mattson, N.S. Potassium-Deficient Nutrient Solution Affects the Yield, Morphology, and Tissue Mineral Elements for Hydroponic Baby Leaf Spinach (Spinacia oleracea L.). Horticulturae 2021, 7, 213. [CrossRef]

11. Butler, J.D.; Oebker, N.F. Hydroponics as a hobby: Growing plants without soil. Circular 1962, 844, 1-16.

12. Jovicich, E.; Cantliffe, D.J.; Stoffella, P.J.; Vansickle, J.J. Reduced fertigation of soilless greenhouse peppers improves fruit yield and quality. Acta Hortic. 2003, 609, 193-196. [CrossRef]

13. Sharma, N.; Acharya, S.; Kumar, K.; Singh, N.; Chaurasia, O.P. Hydroponics as an advanced technique for vegetable production: An overview. J. Soil Water Conserv. 2018, 17, 364-371. [CrossRef]

14. Jensen, M.H. Hydroponics. HortScience 1997, 32, 1018-1021. [CrossRef]

15. Majid, M.; Khan, J.N.; Ahmad Shah, Q.M.; Masoodi, K.Z.; Afroza, B.; Parvaze, S. Evaluation of hydroponic systems for the cultivation of Lettuce (Lactuca sativa L., var. Longifolia) and comparison with protected soil-based cultivation. Agric. Water Manag. 2021, 245, 106572. [CrossRef]

16. Salman, S.A.; Shahid, S.; Afan, H.A.; Shiru, M.S.; Al-Ansari, N.; Yaseen, Z.M. Changes in Climatic Water Availability and Crop Water Demand for Iraq Region. Sustainability 2020, 12, 3437. [CrossRef]

17. Fereres, E.; Soriano, M.A. Deficit irrigation for reducing agricultural water use. J. Exp. Bot. 2006, 58, 147-159. [CrossRef] [PubMed]

18. Perry, C.; Steduto, P.; Allen, R.G.; Burt, C.M. Increasing productivity in irrigated agriculture: Agronomic constraints and hydrological realities. Agric. Water Manag. 2009, 96, 1517-1524. [CrossRef]

19. Tiyasha, T.; Bhagat, S.K.; Fituma, F.; Tung, T.M.; Shahid, S.; Yaseen, Z.M. Dual water choices: The assessment of the influential factors on water sources choices using unsupervised machine learning market basket analysis. IEEE Access 2021, 9, 150532-150544. [CrossRef]

20. Higashitani, K.; Oshitani, J.; Ohmura, N. Effects of magnetic field on water investigated with fluorescent probes. Colloids Surf. A Physicochem. Eng. Asp. 1996, 109, 167-173. [CrossRef]

21. Amiri, M.C.; Dadkhah, A.A. On reduction in the surface tension of water due to magnetic treatment. Colloids Surf. A Physicochem. Eng. Asp. 2006, 278, 252-255. [CrossRef]

22. Saravanan, G.; Ozeki, S. Magnetic field control of electron tunneling pathways in the monolayer of (ferrocenylmethyl)dodecyldimethylammonium bromide on a gold electrode. J. Phys. Chem. B 2008, 112, 3-6. [CrossRef] [PubMed]

23. Surendran, U.; Sushanth, C.M.; Joseph, E.J.; Al-Ansari, N.; Yaseen, Z.M. FAO CROPWAT Model-Based Irrigation Requirements for Coconut to Improve Crop and Water Productivity in Kerala, India. Sustainability 2019, 11, 5132. [CrossRef]

24. Jalili Darbandi Sofla, M.; Norouzi-Apourvari, S.; Schaffie, M. The effect of magnetic field on stability of conventional and pickering water-in-crude oil emulsions stabilized with fumed silica and iron oxide nanoparticles. J. Mol. Liq. 2020, 314, 113629. [CrossRef]

25. Ali, Y.; Samaneh, R.; Kavakebian, F. Applications of Magnetic Water Technology in Farming and Agriculture Development: A Review of Recent Advances. Curr. World Environ. 2014, 9, 695-703. [CrossRef]

26. Maheshwari, B.L.; Grewal, H.S. Magnetic treatment of irrigation water: Its effects on vegetable crop yield and water productivity. Agric. Water Manag. 2009, 96, 1229-1236. [CrossRef]

27. Shukla, S.; Wagh, S.; Vaishamapayan, V.; Gaopande, M.; Vishnoi, A.S.; Wagh, K.K. Magnetic Field Effect on Plant Growth in Hydroponic Farming. Orig. Res. Artic. J. Basic Appl. Res. Int. 2016, 19, $259-262$.

28. Taimourya, H.; Oussible, M.; Baamal, L.; Bourarach, E.H.; Hassanain, N.; Masmoudi, L.; Harif, A. El Magnetically Treated Irrigation Water Improves the Production and the Fruit Quality of Strawberry Plants (Fragaria $\times$ ananassa Duch.) in the Northwest of Morocco. J. Agric. Sci. Technol. B 2018, 8, 145-156. [CrossRef] 
29. Fakhri, N.; Mehdaoui, H.Y.; Elloumi, N.; Kallel, M. Magnetic Treatment Effects on Salt Water and Tomato Plants Growth. Recent Adv. Environ. Sci. from Euro-Mediterr. Surround. Reg. 2017, 1095-1097. [CrossRef]

30. Kareem, N.S.A. Evaluation of Magnetizing Irrigation Water Impacts on the Enhancement of Yield and Water Productivity for Some Crops. J. Agric. Sci. Technol. A 2018, 8, 271-283. [CrossRef]

31. Yusuf, K.O.; Ogunbamowo, T.R.; Obalowu, R.O. Effect of magnetized water on water use efficiency, yield and nutritional qualities of watermelon under deficit irrigation. Agric. Eng. Int. CIGR J. 2020, 22, 51-60.

32. Abdulraheem, L.H.; Jameel, W. Effects of magnetic treatment of different qualities of irrigation water on plant growth. IOP Conf. Ser. Earth Environ. Sci. 2021, 779, 12030. [CrossRef]

33. Lin, I.J.; Yotvat, J. Exposure of irrigation and drinking water to a magnetic field with controlled power and direction. J. Magn. Magn. Mater. 1990, 83, 525-526. [CrossRef]

34. Hozayn, M.; Saeed, A.M.; Qados, A. A Magnetic water application for improving wheat (Triticum aestivum L.) crop production. Agric. Biol. J. N. Am. 2010, 1, 677-682.

35. Moussa, H. The impact of magnetic water application for improving common bean (Phaseolus vulgaris L.) production. N. Y. Sci. J. 2011, 4, 15-20.

36. Fernando, F.P.; Luis, R.A.G.F.; Antonio, E.K.; da Silva Junior, J.F.; Camila, P.C.; Rafael, L. Response of lettuce crop to magnetically treated irrigation water and different irrigation depths. Afr. J. Agric. Res. 2015, 10, 2300-2308. [CrossRef]

37. Wang, Y.; Wei, H.; Li, Z. Effect of magnetic field on the physical properties of water. Results Phys. 2018, 8, 262-267. [CrossRef]

38. Khater, R.M. Effect of fertilization and irrigation with magnetic water on the productivity of marjoram plant. Arab. J. Agric. Sci. 2020, 3, 1-30. [CrossRef]

39. Hozayn, M.; Elaoud, A.; Attia Abd El-Monem, A.; Ben Salah, N. Effect of magnetic field on growth and yield of barley treated with different salinity levels. Arab. J. Geosci. 2021, 14, 701. [CrossRef]

40. Zhou, B.; Yang, L.; Chen, X.; Ye, S.; Peng, Y.; Liang, C. Effect of magnetic water irrigation on the improvement of salinized soil and cotton growth in Xinjiang. Agric. Water Manag. 2021, 248, 106784. [CrossRef]

41. Smith, D.C.; Hughes, J.C. Changes in chemical properties and temperature during the degradation of organic wastes subjected to simple composting protocols suitable for small-scale farming, and quality of the mature compost. S. Afr. J. Plant Soil 2002, $19,53-60$.

42. Jackson, M.L. Soil Chemical Analysis. J. Agric. Food Chem. 1959, 7, 138. [CrossRef]

43. James, L.G. Principles of Farm Irrigation Systems Design; John Wiley and Sons Limited: Hoboken, NJ, USA, 1988; ISBN 047183954X.

44. Burt, C.M.; Clemmens, A.J.; Strelkoff, T.S.; Solomon, K.H.; Bliesner, R.D.; Hardy, L.A.; Howell, T.A.; Eisenhauer, D.E. Irrigation Performance Measures: Efficiency and Uniformity. J. Irrig. Drain. Eng. 1997, 123, 423-442. [CrossRef]

45. American Society of Agricultural Engineers. Test Procedure for Determining the Uniformity of Water Distribution of Center Pivot and Lateral Move Irrigation Machines Equipped with Spray or Sprinkler Nozzles. 2003. Available online: https://www.canr. msu.edu/uploads/235/67987/ASAE_S436.1.pdf (accessed on 8 January 2022).

46. Surendran, U.; Sandeep, O.; Joseph, E.J. The impacts of magnetic treatment of irrigation water on plant, water and soil characteristics. Agric. Water Manag. 2016, 178, 21-29. [CrossRef]

47. Yang, F.; Fan, Y.; Wu, X.; Cheng, Y.; Liu, Q.; Feng, L.; Chen, J.; Wang, Z.; Wang, X.; Yong, T.; et al. Auxin-to-Gibberellin Ratio as a Signal for Light Intensity and Quality in Regulating Soybean Growth and Matter Partitioning. Front. Plant Sci. $2018,9,56$. [CrossRef] [PubMed]

48. Yang, F.; Liao, D.; Wu, X.; Gao, R.; Fan, Y.; Raza, M.A.; Wang, X.; Yong, T.; Liu, W.; Liu, J.; et al. Effect of aboveground and belowground interactions on the intercrop yields in maize-soybean relay intercropping systems. F. Crop. Res. 2017, 203, 16-23. [CrossRef]

49. Zlotopolski, V. Magnetic Treatment Reduces Water Usage in Irrigation Without Negatively Impacting Yield, Photosynthesis and Nutrient Uptake in Lettuce. Int. J. Appl. Agric. Sci. 2017, 3, 117. [CrossRef] 